\title{
Metaphors in Managerial and Employee Sensemaking in an Information Systems Project
}

Hekkala, Riitta; Stein, Mari-Klara; Rossi, Matti

\author{
Document Version \\ Accepted author manuscript \\ Published in: \\ Information Systems Journal
}

DOI:

$10.1111 /$ isj. 12133

Publication date:

2018

License

Unspecified

Citation for published version (APA):

Hekkala, R., Stein, M-K., \& Rossi, M. (2018). Metaphors in Managerial and Employee Sensemaking in an Information Systems Project. Information Systems Journal, 28(1), 142-174. https://doi.org/10.1111/isj.12133

Link to publication in CBS Research Portal

\section{General rights}

Copyright and moral rights for the publications made accessible in the public portal are retained by the authors and/or other copyright owners and it is a condition of accessing publications that users recognise and abide by the legal requirements associated with these rights.

\section{Take down policy}

If you believe that this document breaches copyright please contact us (research.lib@cbs.dk) providing details, and we will remove access to the work immediately and investigate your claim.

Download date: 26. Apr. 2023

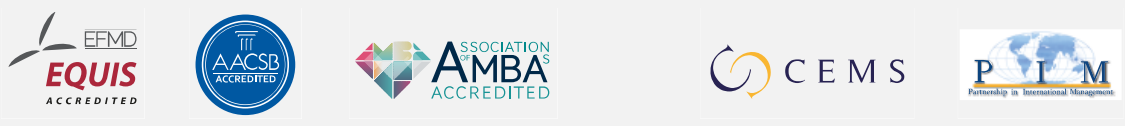




\section{Metaphors in Managerial and Employee Sensemaking in an Information Systems Project}

Riitta Hekkala, Mari-Klara Stein, and Matti Rossi

Journal article (Accepted manuscript*)

\section{Please cite this article as:}

Hekkala, R., Stein, M-K., \& Rossi, M. (2018). Metaphors in Managerial and Employee Sensemaking in an Information Systems Project. Information Systems Journal, 281), 142-174. 001: 10.1111/isj.12133

This is the peer reviewed version of the article, which has been published in final form at DOI: https://doi.org/10.1111/isj.12133

This article may be used for non-commercial purposes in accordance with Wiley Terms and Conditions for SelfArchiving

* This version of the article has been accepted for publication and undergone full peer review but has not been through the copyediting, typesetting, pagination and proofreading process, which may lead to differences between this version and the publisher's final version AKA Version of Record. 


\section{METAPHORS IN MANAGERIAL AND EMPLOYEE SENSEMAKING IN AN INFORMATION SYSTEMS PROJECT}

Riitta Hekkala, Aalto University, School of Business, riitta.hekkala@aalto.fi (corresponding author)

Mari-Klara Stein, Copenhagen Business School, mst.itm@cbs.dk

Matti Rossi, Aalto University, School of Business, matti.rossi@aalto.fi

Note: this is an authors' version of the paper Hekkala, R., Stein, M. -K., and Rossi, M. (2016) Metaphors in managerial and employee sensemaking in an information systems project. Info Systems Journal, doi: 10.1111/isj.12133.

The paper is provided for non-commercial use. The final published version as it appears in the journal (PDF and HTML) is available at:

http://onlinelibrary.wiley.com/doi/10.1111/isj.12133/abstract?campaign=wolearl yview 


\begin{abstract}
This longitudinal study looks at the metaphors used in a public sector information systems development project from the perspective of cognitive metaphor theory (Lakoff \& Johnson, 1980). We examine the use of metaphors by project team members, including representatives of the users, software developers, and the managers guiding the project work. The findings indicate that project team members and managers use a rich set of metaphors to make sense of the project and the records management system they are working on. Notably, distinct sets of metaphors are used in different project phases and among the project personnel and management. As the differences in the metaphors also coincide with key events in the trajectory of the project, we contend that metaphors have significant power in sensemaking, influencing action, and project outcomes. In particular, we find that in highly ambiguous, knowledge-intensive situations, metaphor use with unclear intentions and purpose hinder learning and create more chaos than order. From a practical perspective, our study highlights the relevance of metaphor use for project management. We suggest that intentional selection of metaphors by management could be beneficial for many complex information systems projects.
\end{abstract}

Keywords: Metaphors, Information systems development, Sensemaking, Cognitive metaphor theory, Qualitative case study 


\section{INTRODUCTION}

Metaphors are poorly understood phenomena in the field of Information Systems (IS) (Schultze \& Leidner, 2002). Nonetheless, during the past 30 years, a number of studies have been conducted on metaphors and their role in information systems development (ISD) (e.g. Heiskanen \& Similä, 1992; Hirschheim \& Newman, 1991; Ives \& Learmonth, 1984; Kendall \& Kendall, 1993; Robey, Wishart \& Rodriguez-Diaz, 1995; Schultze \& Leidner, 2002; Walsham, 1991). Several studies (Hirschheim \& Newman, 1991; Kendall \& Kendall, 1993; Schultze \& Leidner, 2002; Smolander, Rossi \& Purao, 2008) have revealed that metaphors have 'true power' to shape the reality and thoughts of the people who are caught up in particular behaviour. Kendall and Kendall (1993, p. 149) state for example: "If we rejoice in the fact that the company's reputation is soaring like an eagle, or warn that an executive will go down with the ship, we have used metaphors to expand the understanding of the listener and have empowered them to see the world differently." Recent studies (e.g. Cornelissen, 2012; Cornelissen \& Clarke, 2010; Maitlis \& Christianson, 2014) have been significant in explaining the power of metaphor in the processes of sensemaking, as metaphors are often evaluative and can provide justification for actions. The role of sensemaking in the creation of meaning is particularly critical to investigate when individuals in positions of power, such as managers, are considered (e.g. SmithDoerr, Manev \& Rizova, 2004). Sensemaking, on one hand, "has to do with the way managers understand, interpret, and create sense for themselves" (Rouleau, 2005, p. 1415). However, these interpretations and understandings are also shared by managers, which gradually defines or creates meaning through discussion (Weick, 1995, p. 99, based on Huber \& Daft, 1987, p. 151).

Cognitive scientists (Lakoff \& Johnson, 1980) have examined metaphors in detail, suggesting that metaphorical concepts are essential to thought - without metaphors we could understand very little beyond our direct physical experience. Lakoff and Johnson demonstrated that the human conceptual system is metaphorical by nature: we think by metaphors and act accordingly. They also showed that metaphors have power: "each metaphor highlights certain aspects of the concept and implicitly hides others" (op.cit, p. 201). The goal of this research is to use cognitive metaphor theory as a lens to understand the metaphors used in an IS development project. We contend that this provides an alternative view on how people make sense of ISD projects and is useful not only in thinking about the language used in such projects, but also in trying to understand the complexities of metaphoric thought patterns, and subsequent actions, over time. Metaphors can be argued to be particularly important in IS projects because of the inherent ambiguities that stem from managers, developers, and users having different orientations towards the project (cf. Hirschheim, Klein \& Lyytinen, 1996). Metaphors are 
thus needed to frame and make sense of the project - decide 'how things are around here' and how to behave accordingly (cf. Nicholson \& Anderson, 2005). To understand 'how things were' in the project studied, we were guided by the following question: How are metaphors used in managerial and employee sensemaking in an IS development project?

The contribution of this paper is threefold: descriptive, theoretical and practical. First, we describe common metaphors used in an ISD project, how managers and project personnel use the metaphors differently to understand the situations in the project and frame the future of the project through them. Second, we contribute to the theoretical conceptualization of metaphors' role in sensemaking. In extant sensemaking literature (both in and outside of IS contexts), effective sensemaking is generally considered purposeful (or mindful) (Aanestad \& Jensen, 2016; Sutcliffe \& Weick, 2006), and metaphors as key sensemaking devices (Davison, et al., 2004; Maitlis \& Christianson, 2014). Cognitive metaphor theory (Lakoff and Johnson, 1980), conversely, suggests that metaphor use by individuals is often habitual, unintentional and even mindless. Yet there is very little we know of this tension of mindless metaphor use in efforts of mindful sensemaking. Our study contributes here by suggesting that in highly ambiguous, knowledge-intensive situations, metaphor use with unclear intentions and purpose will result in these sensemaking devices creating more chaos than order, and rather than facilitating learning, hindering it. Third, based on these insights we offer practical recommendations for guided sensemaking in IS projects.

The rest of this paper is organized as follows. In the next section, we present a definition of metaphor, the basic ideas of cognitive metaphor theory (Lakoff \& Johnson, 1980), approaches that have been adopted by IS researchers for studying metaphors, and the role of metaphors in sensemaking. The following three sections present the research case, the research method and our findings. In the final sections, we discuss the theoretical and practical implications of our findings and conclude the paper.

\section{METAPHOR, SENSEMAKING AND INFORMATION SYSTEMS}

In the following sections we discuss the definition of metaphor, the basic elements of cognitive metaphor theory (Lakoff \& Johnson, 1980), consider the role of metaphors in sensemaking, and highlight the relevance of both to the information systems field.

\section{DEFINITION OF METAPHOR AND KEY ASPECTS OF COGNITIVE METAPHOR THEORY}

Metaphor is seen as "a way of thinking and a way of seeing that pervade how we understand our world generally" (Morgan, 1986, p. 12), and as a cognitive lens we use to make sense of different 
situations (Kendall \& Kendall, 1993). The essence of metaphor is that a certain issue is understood and interpreted in terms of another (Lakoff \& Johnson, 1980). Typically, metaphors help us understand a more abstract conceptual domain (such as 'life', 'time', 'emotions', 'communication', 'the mind', 'ideas', 'institutions', or 'interpersonal relationships') in terms of a more tangible and familiar one (such as 'food', 'journeys', 'space', 'motion', 'objects'). For example, we often make sense of undesirable sequences of events in life as 'losing our way', implying and hoping that it is possible to find the right way again. However, there is no single, tangible or nonmetaphorical concept which could ever structure or define an abstract concept in the right way. As a result, abstract concepts are typically defined metaphorically in terms of multiple tangible concept(s). "Thus, we understand abstract concepts in terms of many metaphorical definitions, each of which captures part of the concept" (Lakoff \& Johnson, 1980, p. 4). A good example of an abstract notion defined metaphorically by a number of different, more tangible concepts is the idea of life: it is often made sense of as a canvas, a river, a story, a box of chocolates, a song, a game, just to mention a few. Metaphorical definitions of the same idea can even be contradictory, as demonstrated by our research case where an IS project is made sense of, for example, as a war and a honeymoon simultaneously.

Metaphors are not just for 'the poetic imagination' or 'the rhetorical flourish'; it is abundant in everyday language, thought and action (Lakoff \& Johnson, 1980). Thus, the human conceptual system plays a critical role in defining everyday realities. Lakoff and Johnson go as far as to argue that human experience and action are very much a matter of metaphor. As a result, in much of our everyday life (i.e., outside 'poetic' contexts), we rely on metaphors and other figures of speech without really noticing them. For example, we often define time in terms of money, without reflecting on the implications of this kind of thinking. This can numb us to the fact that these linguistic devices often maintain our implicit agreement to the dominant ways of thinking and acting in our society (Chandler, 2002; Davison, Boswood \& Martinsons, 2004; Lakoff \& Johnson, 1980).

Lakoff and Johnson (1980) present metaphors in capital letters to highlight the focus on concepts, rather than just words. The above-mentioned relationship between time and money is described in their notation in the following way: 'TIME IS MONEY'. We adopt this notation style in our paper as well. In language, the metaphor 'TIME IS MONEY' is visible in the ways people talk about time by using the same terms as when talking about money; for example, 'please do not waste my time' and 'I've invested a lot of time in her'. Such statements are so commonplace in our everyday life that we hardly notice the peculiarity of thinking about time in such a way. 


\section{METAPHOR STUDIES IN INFORMATION SYSTEMS}

In the IS research literature, various approaches have been taken to studying metaphors. Two lines of research are particularly relevant for the purposes of this paper: 1) studies looking at specific metaphors (e.g., gatekeeping) to understand the process of ISD (Heiskanen \& Similä, 1992), and 2) studies utilizing various frameworks (Schultze \& Leidner, 2002) or theoretical lenses (Hekkala, von Hellens \& Newman, 2012; Walsham, 1991) to understand issues in ISD through metaphors. Our study follows the first line of research and explores specific metaphors used for sensemaking in an ISD project.

Earlier metaphor studies in the first line of research have tried to explain, for example, relationships between the stakeholders in ISD work. Heiskanen and Similä (1992) have chosen the gatekeeper metaphor to understand the evolution of the interaction patterns between software developers and users. Kendall and Kendall (1993) investigated the language of IS users in 16 organizations. They identified 9 metaphors (journey, war, game, organism, society, machine, family, zoo, and jungle) and suggest that most of these metaphors are commonly used in systems development methodologies. Metaphors like 'Blueprint', 'Literature', 'Language' and 'Decision' were identified by Smolander, Rossi and Purao (2008, p. 575) as part of the vocabulary "that stakeholders use to understand the term software architecture, which in turn allows them to effectively participate in its creation and use." Hirschheim and Newman (1991) discuss ISD through three different metaphors: ISD as a battle, organizations as fiefdoms and man as a machine. Other studies in the IS field have also used 'war' as a metaphor: for example, information systems have been seen as competitive weapons (e.g., Ives \& Learmonth, 1984). Similarly to our own study, Davison et al. (2004) consider conceptual, i.e., basic, conventional metaphors such as 'CHANGE IS A JOURNEY', and generative, that is, novel, uncommon metaphors that can generate new interpretations, as tools for instigating and communicating strategic change. The specific role metaphors may play in influencing change (e.g., guiding an evolving IS project) leads us to considering sensemaking - "the process through which individuals work to understand novel, unexpected, or confusing events" or, in other words, understand change (Maitlis \& Christianson, 2014, p. 58).

\section{METAPHORS AND SENSEMAKING}

In recent years metaphors have had a renaissance in the sensemaking literature (e.g. Cornelissen, 2005; Cornelissen, Oswick, Christensen, \& Phillips, 2008; Nicholson \& Anderson, 2005). Maitlis and Christianson (2014) highlight the importance of metaphors as resources for sensemaking, particularly in the gradual creation and diffusion of meaning through discussion. Sensemaking refers to the process 
through which individuals work to understand change and explain one's previous actions to oneself and others (Weick, 1995). As such, sensemaking allows individuals to deal with uncertainty, create plausible accounts of what, when and why something is happening, and continue to act in and enact their environment accordingly (ibid.). The studies of metaphor in sensemaking have demonstrated how metaphors "connect cues and frames" and are a fundamental act of sensemaking (Gioia et al., 1994; Grant \& Oswick, 1996; Hill \& Levenhagen, 1995), participate in the construction of social identity (e.g. Gioia et al.1994), and provide justification for actions (Cornelissen 2005, 2012; Cornelissen \& Clarke, 2010). Sensemaking is triggered by cues (unexpected, surprising or confusing events and actions). Metaphors are powerful in sensemaking not only because they enable individuals to create order in these unexpected or confusing situations (i.e., interpret and explain cues), but also because metaphors are often "evaluative and provide justification for certain actions [...], validating some accounts and discrediting others" (Maitlis \& Christianson, 2014, p. 83). Certain interpretations of cues, thus, become more "valid" and more influential in justifying previous actions and directing future actions. Sensemakers' use of metaphors also varies depending on their relationship to the issue in question and their audience (e.g. Cornelissen, 2012). Factors such as role-situated commitment to carrying out certain activities as part of a professional role, the salience of others' expectations, and understanding of the strategic change itself can shift the use of metaphors.

A fundamental tenet of sensemaking is that it is always recursively linked with action (Maitlis \& Christianson, 2014; Weick, 1995). Metaphors as part of sensemaking are, thus, never just about cognition and language use, but are directly influential in individuals' behaviour, as considered next.

\section{Metaphors, Sensemaking and Action: What Can Metaphors Accomplish in IS Projects?}

Individuals' behaviours and actions generate cues, which serve as input for sensemaking. People interpret these cues, take action, pay attention to further cues generated by their actions, and either continue doing what they have been doing or take revised action. In sum, "action serves as fodder for new sensemaking, while simultaneously providing feedback about the sense that has already been made" (Maitlis \& Christianson, 2014, p. 84). For example, project team members can make sense of cues of poor performance via the metaphor of a steep learning curve, enabling them to justify their actions and keep acting in the same way (cf. Weick \& Sutcliffe, 2003). As individuals take action, they shape the environment in which sensemaking takes place - a process known as "enactment". Through action, individuals change and create the situations and cues they then have to make sense of (Maitlis \& Christianson, 2014). This recursive relationship is what differentiates sensemaking from interpretation. Sensemaking is not just about individuals understanding and explaining the 
environment they find themselves in, crucially, sensemaking is also about creating that environment (ibid.).

With this powerful ability to create and shape environments, effective sensemaking has been found to be able to guide strategic change (Corley \& Gioia, 2004) and facilitate learning from errors (Haas, 2006). For example, studies have shown that misdirected sensemaking can have severe long-term implications for change initiatives. $\mathrm{Yu}$, et al. (2005) demonstrated how a change initiative failed to improve patient care, because the team spent most of their effort making sense of internal administrative and integration issues, and little effort on the challenge of integrating with other units within the health care system. Other studies have shown the critical importance of effective sensemaking in learning (Haas, 2006; Kayes, 2004). For example, failures to appreciate ambiguity can lead teams to continue working in an established way, without paying attention to new information, the need to re-interpret cues and the need for changes in action. In worst cases, this can result in total breakdown in learning and dreadful consequences (Kayes examined the 1996 Everest disaster in which eight individuals died). However, high levels of ambiguity are also characteristic to more mundane situations, where it may not be lives that are at stake but projects worth millions. As Haas (2006) highlights, knowledge-intensive work settings are one particular environment characterized by high ambiguity: significant uncertainty, unclear cues, abundance of information on problems and solutions, equivocal relationships between actions and outcomes. In such environments, it is especially critical that teams engage in effective sensemaking (identifying key problems, key solutions, deciding what to focus on), because without it teams are unable to evaluate their actions and learn from failed actions.

Information systems development projects, such as the one studied in this paper, are knowledgeintensive environments trying to accomplish strategic change, and are often characterized by these ambiguities. First, IS projects are nonroutine environments with high uncertainty about which of the many possible problems to prioritize or how to know which of the options at each time is the best one. Additionally, information system development projects focus heavily on the outcome, yet the quality of the project that can be delivered to clients can hardly be guaranteed. The quality of the project depends to a large extent on the individuals and teams involved in IS projects and their knowledgeintensive work (e.g., gathering information and know-how through interpersonal exchanges and applying this knowledge to produce deliverables) (cf. Haas, 2006). Metaphors and sensemaking, thus, have the potential to facilitate the successful guiding of ISD projects and learning by the people involved (cf. Aanestad \& Jensen, 2016). Yet studies also show the potential for misdirected sensemaking ( $\mathrm{Yu}$, et al. 2005), metaphors hindering change (Weick \& Sutcliffe, 2003), and breakdowns in learning (Haas, 2006). The causes for these varying outcomes often lie with the well- 
known distinction between mindful and mindless sensemaking (Aanestad \& Jensen, 2016; Seiling \& Hinrichs, 2005; Weick \& Sutcliffe, 2006). However, when considering the role of metaphor in sensemaking we run into an unresolved tension - as considered next.

\section{Mindful Sensemaking, Mindless Metaphor Use?}

Sensemaking is generally seen as a "rational, intellectual process" that requires continuous, conscious effort (Cunliffe \& Coupland, 2012, p. 65; Klein, et al. 2006). It involves "attending to and bracketing cues in the environment" (Maitlis \& Christianson, 2014, p. 67), and a "motivated, continuous effort to understand connections (which can be among people, places, and events) in order to anticipate their trajectories and act effectively" (Klein, et al. 2006, p. 71). Effective sensemaking is considered to rely on mindful attending, bracketing, and understanding - continuous updating of information, learning from the past, willingness to consider alternatives, and the like (Weick \& Sutcliffe, 2006). It has also been suggested that, in fact, mindless and mindful actions depend on each other and there cannot be one without the other (Carlo, et al., 2012). The point we wish to draw attention to is that sensemaking research has expended considerable effort in studying and identifying various forms of purposeful, effective or mindful sensemaking that can lead to successful outcomes. For example, extant research has described prospective sensemaking (Gioia, et al., 1994), future-oriented sensemaking (Gephart, et al., 2010), and sensegiving (Maitlis \& Lawrence, 2007; Vlaar, et al., 2008) - all processes related to strategic and intentional meaning construction and shaping of reality not just for oneself but also for others. Studies have also examined the various conditions under which leaders can more or less successfully guide sensemaking and ensure success. For example, Maitlis (2005) found that depending on leader and stakeholder behaviour, four different types of sensemaking can occur: "Guided" (leaders promote and shape understanding, stakeholders actively participate in the process); "Fragmented" (stakeholders raise various issues, but leaders do not control or guide the process); "Restricted" (leaders dominate sensemaking, while stakeholders accept dominant accounts without much questioning); and "Minimal" (neither leaders nor stakeholders try to actively shape sensemaking; sensemaking usually happens ad-hoc in response to external triggers).

Conversely, the use of metaphors in effective sensemaking has not received similar scrutiny. As highlighted by studies on metaphors conducted in the IS field, metaphors can help understand highly abstract and ambiguous technologies, systems development choices and complex interactions between managers, developers and users (Hirschheim \& Newman, 1991; Kendall \& Kendall, 1993; Smolander, et al., 2008). Sensemaking literature firmly attests to the metaphors' ability to create order, evaluate and justify actions, and thus, validate and direct certain courses of action taken (Cornelissen 2005, 2012). While there is considerable reflection on some metaphors being better (more constructive, 
generative) than others (Davison, et al., 2004; Kendall \& Kendall, 1993), the fundamental issue that many metaphors are used habitually and non-intentionally has received limited attention. In sum, while cognitive theorists emphasize that in much of our everyday life we rely on metaphors without really noticing them (Chandler, 2002; Lakoff \& Johnson, 1980), sensemaking literature suggests that metaphors play an important role in intentional and deliberate sensemaking. In this paper we aim to examine how metaphors are used in managerial and employee sensemaking in an IS development project by explicitly taking these conflicting ideas into consideration, thus, advancing our understanding of the role of metaphors in sensemaking, specifically in highly ambiguous environments, such as ISD projects.

\section{METHODOLOGY}

The broader aim of this study is to understand issues that make the development of public sector information systems difficult, through a study of a records management system (RMS) being developed in three public sector organizations (Alpha, Beta and Gamma) in Finland. Below, we aim to present this complex project as accurately as possible. Unfortunately, as a large inter-organizational project in a small country, the project is vulnerable to identification if we provide too much detail, and we are bound by ethical considerations as to how much information we can reveal.

The goal of the new records management system was to provide a centralized means of collecting customer information (e.g., personal information, such as age, gender, and address, as well as data on the services the organizations had provided the customers with). In addition, the system should also facilitate the dissemination of certain information back to the customers, as well as offer web-based self-service capabilities. All three organizations were from the same sector, so their requirements for the system were fundamentally the same. Alpha, Beta and Gamma had decided to modernize their IS because the current RMS and the platform it had been developed on, were coming to the end of their lifecycles, and their maintenance was increasingly difficult. It was also easier to develop a new IS together because of budgetary constraints in all the organizations. Bespoke development was chosen over buying a packaged solution as suitable packaged software capable of meeting the requirements of public sector organizations could not be found.

The project began in 2013. At this time, the project involved only the three main user organizations (Alpha, Beta and Gamma), however by May 2014 the first external software house (Omicron), supplying software developers, joined the project. Omicron's involvement in the project was specified in an agreement with Beta. Another external software company (Midén) then joined the project in spring 2015. Midén's involvement in the project was specified in an agreement with Alpha. In 
addition to these two supplier organizations, a global design company and another software house also became involved in the project. Both supplied a user interface designer to work on the project. A fourth user organization (Delta) joined in 2015. While all stakeholders played a role in the unfolding of the project events, for the purposes of this paper we interviewed the key 'sensemakers', that is, project staff (managers and employees) from the three main initiator organizations (Alpha, Beta and Gamma).

It is important to describe the legacy systems at the three organizations briefly to contextualize the current ISD project. Alpha and Beta shared a legacy RMS, which, as mentioned above, was coming to the end of its lifecycle and had numerous weaknesses. For example, it required a lot of manual data entry and re-entry, processing and paperwork, and information security was very poor. The legacy records management system had been in operational use since the 1990s and had been developed further during that time to automatize work. These previous development projects were often referred to by our interviewees, most of whom had been part of all or some of the prior efforts to modernize the system. Gamma, on the other hand, had a different legacy RMS, which worked quite well. Gamma's reputation as being technologically progressive, as well as its existing RMS were seen by the project partners as providing many valuable ideas for identifying the basic requirements for the functionality of the new system. Because of the different financial situations of the organizations, the project expenses were not divided equally: Alpha was expected to cover $30 \%$, Beta $50 \%$, and Gamma $20 \%$ of the costs. The project organization was established in early 2013 and consisted of three different groups: the project group, steering group and management group, each including representatives of the three organizations (Alpha, Beta and Gamma).

\section{DATA COLLECTION}

To examine metaphors and sensemaking in the described project, we have chosen a qualitative case study approach. Our data consists of 34 in-depth interviews, collected in three phases: March-April 2013, May-June 2014, and May-August 2015 (see Table 1). For the purposes of this paper, we decided to exclude the steering group from our analyses, as the members of this group were not as intensively involved in the day-to-day project work as the other groups. Thus, their interviews provided less in terms of rich and detailed accounts of everyday project life (including the use of metaphors and descriptions of sensemaking). Accordingly, while we did interview steering group members, our analyses are based on a set of 34 interviews with project and management groups. All interviews were recorded and fully transcribed. 
In the first phase, we interviewed all personnel assigned to work on the project from Alpha, Beta and Gamma. The second phase of data collection (2014) consisted largely of follow-up interviews with the people interviewed earlier, but for some project participants (who started later in the project), this was the first interview. In the third phase of data collection (2015), we interviewed again project members belonging to the Alpha, Beta and Gamma organizations; but also the representatives of the external partner organizations who had joined the project later on. The nature of all the interviews was open; the main focus was on the experience of the project members. The interviewees were asked to describe their own experiences in the project and their thoughts about its progress, followed by a few semistructured questions, which we posed to all participants (covering topics regarding challenges in the project, among others). Table 1 shows the key interviewees (from the main three organizations, Alpha, Beta and Gamma), their roles, home organization and the group they belong to in the project, as well as how many times each person was interviewed. We changed the names of all project members to conceal their identities. The three-phase data collection provided us with the opportunity to follow the development of the project, thus allowing us to gain a deeper understanding of the metaphors and sensemaking processes.

\begin{tabular}{|c|c|c|c|}
\hline Project Group & Role & Members & \# of Interviews \\
\hline \multirow{7}{*}{$\begin{array}{l}\text { MANAGEMENT } \\
\text { GROUP } \\
\text { (16 interviews } \\
\text { altogether) }\end{array}$} & \multirow{7}{*}{$\begin{array}{l}\text { The members of the management } \\
\text { group decide on all personnel and } \\
\text { budgeting issues. They guide other } \\
\text { project groups and define general } \\
\text { policies. It is also the duty of the } \\
\text { management group to take a stand } \\
\text { on issues, which the project group } \\
\text { or steering group are not able to } \\
\text { solve. The members of the } \\
\text { management group have different } \\
\text { roles in their home organizations. } \\
\text { For example, Ben, Ewan and Sean } \\
\text { are IT managers and Lily, Kelly and } \\
\text { Leon are service managers. In the } \\
\text { project, Lily is the project leader } \\
\text { and also a member of the steering } \\
\text { group. }\end{array}$} & Lily (Beta) & 3 \\
\hline & & Kelly (Alpha) & $\begin{array}{l}1 \text { (left the project } \\
\text { in June 2013) }\end{array}$ \\
\hline & & Leslie (Alpha) & $\begin{array}{l}1 \text { (started in June } \\
2013, \text { substituting } \\
\text { for the role Kelly } \\
\text { had) }\end{array}$ \\
\hline & & Leon (Gamma) & 3 \\
\hline & & Ewan (Alpha) & 3 \\
\hline & & Ben (Beta) & 3 \\
\hline & & Sean (Gamma) & $\begin{array}{l}2 \text { (Left the project } \\
\text { in 2014) }\end{array}$ \\
\hline \multirow{5}{*}{$\begin{array}{l}\text { PROJECT } \\
\text { GROUP } \\
\text { (18 interviews } \\
\text { altogether) }\end{array}$} & \multirow{5}{*}{$\begin{array}{l}\text { The aim of the project group is to } \\
\text { find possible technical solutions for } \\
\text { the new registrar system and to } \\
\text { make sure that the processes are } \\
\text { defined and done by people who } \\
\text { know the substance well. } \\
\text { The group has software developers } \\
\text { and representatives of users. These } \\
\text { individuals also have different roles } \\
\text { in their home organizations } \\
\text { (project designer, coordinator, } \\
\text { user). }\end{array}$} & Alex (Alpha) & 3 \\
\hline & & Isaac (Gamma) & 2 \\
\hline & & Carol (Alpha) & 3 \\
\hline & & Jacob (Beta) & $\begin{array}{l}1 \text { (left the project } \\
\text { in September } \\
\text { 2013) }\end{array}$ \\
\hline & & Amber (Beta) & $\begin{array}{l}2 \text { (left the project } \\
\text { in September } \\
\text { 2013) }\end{array}$ \\
\hline
\end{tabular}




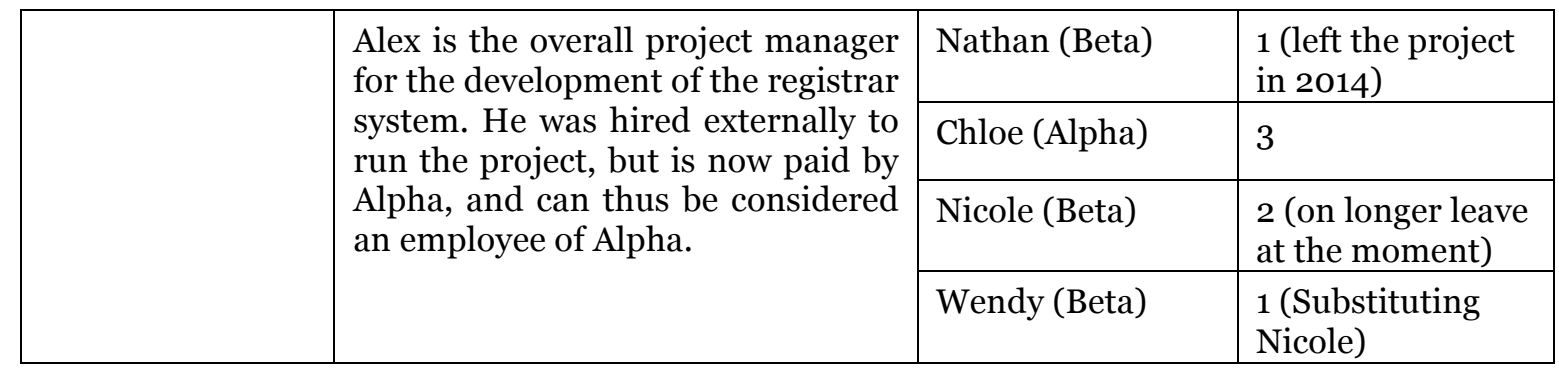

Table 1. Overview of Data Collection

\section{DATA ANALYSIS}

We analyzed the data by using cognitive metaphor theory (Lakoff \& Johnson, 1980) as a lens to describe the common metaphors used in the project. In the first phase, we identified all kinds of figurative expressions (e.g., metaphors, idioms, irony) used by the project members in the interviews. In the second phase, we deliberately excluded common idioms and other non-metaphoric figures of speech. For example, idioms such as "behind someone's back" and "keep an eye out" (e.g. Niergarth, 2007) were excluded at this point because they occurred so frequently. Common idioms like these are more likely to show established organizational-cultural conversation patterns ${ }^{1}$ (Sinclair, 1991) rather than particular ways of making sense of an IS project. We then grouped the identified metaphors into different categories according to theme: 1) war and battle, 2) games and exercising, 3) nature, 4) family, 5) journey, 6) building, 7) illness and medication, 8) Bible and religion, 9) zoo and animal, and 10) food and clothes. These metaphors are described and illustrated in Appendix 1. We coded the metaphors by using the notation style of Lakoff and Johnson (1980). For example, Ben (IT manager, Beta, management group) described a previous project as " $a$ war that wore out both men and women... many come along with a will, and after a while [become] absolutely worn out...". Based on the notion that metaphors are visible in the language of people, and using the notation style of Lakoff and Johnson (ibid.), we coded this in the following way: 'INFORMATION SYSTEMS PROJECT IS A WAR'. Rather than just identifying themes (e.g., war), this notation style allowed us to keep track of which concepts were thought of as war. As the examples in Appendix 1 demonstrate, metaphors are used not just to describe the project as a whole, but also to describe project personnel and the system.

\footnotetext{
${ }^{1}$ Common idioms are part of our everyday speaking patterns, where we have the tendency to speak in whole phrases (stretches of language with a single meaning) rather than individual words: "a language user has available to him or her a large number of semi-preconstructed phrases that constitute single choices" (Sinclair, 1991, p. 110).
} 
After we had coded the data for metaphors, we then focused on the use of metaphors as fundamental acts of sensemaking and the links between sensemaking and the trajectory of the IS project. In order to do so, we linked the use of metaphors to particular groups (project and management), to people with different roles in these groups (managerial vs. employee roles), as well as the project phases for which we had collected data (labelled as requirements specification, and design and implementation phases based on the project member's own terminology). While the groups organized people in the project in a particular way, the roles individuals had in the project did not always follow these group boundaries. For example, the project manager (Alex) was assigned to the project group to work closely with the key people designing and developing the system, but his role was clearly managerial, and thus similar to the roles of the individuals in the management group. Therefore, it was more fruitful to analyze sensemaking (use of metaphors) in relation to roles (e.g., managers and project workers), rather than groups. In order to analyze how metaphors are a part of sensemaking, we focused on the most common metaphors used across roles (see Appendix 3 where the use of metaphors and the frequency numbers for different metaphors over time are shown per each key respondent). We traced the use of identified metaphors in context by focusing on how the project members described: a) their reactions to what others said and did, particularly in relation to our identified metaphors, and $b$ ) the development of the project and various factors they thought impacted it.

It should be noted that the language of the interviews, and thus of the metaphors, was Finnish, and some of the metaphors translate poorly. Furthermore, the Finnish population is quite homogenous, and the integrated common school system leads to a reasonably uniform culture. This can be seen, for example, in prevalent war metaphors (in Finnish "se oli sota joka söi miestä ja naista", translated as: "a war that wore out both men and women..."), influenced by Finland's complicated wartime history, and similarly frequent biblical metaphors (in Finnish "järjestelmä tulee, oletko valmis", translated as: "the system is coming soon, are you ready"), which can be traced to the protestant church connection of the state in an otherwise secular country. We provide further details on the Finnish culture (and its possible impact on common metaphors) in Appendix 2. On a conceptual level, metaphors work similarly in different contexts and cultures (Lakoff \& Johnson, 1980), but we acknowledge the problems of 'lost in translation' when explaining the use of some of the metaphors. We have tried our best to translate the metaphors described in the paper into English, but the analysis was performed based on the original Finnish versions of the interviews. 


\section{RESEARCH CASE}

As indicated above, the project organization was established in early 2013. The phase of requirements specification also began at this time, with the goal of finding the most suitable technologies for the project. While the project expenses were not equally divided, the three organizations had equal voting rights:

"Every organization will have one vote. In order to maintain policy-making, it is easier that 21 votings are possible, and deadlocks should not happen... a deadlock can only happen if one organization will refuse to join in the decision-making, in which case the whole shebang will fail...” (Alex, project manager, Alpha).

All members also agreed on the management- steering-, and project group structure and relied on it to be able to openly discuss and resolve any issues arising in the project. The project manager's selfprofessed leadership style emphasized 'self-direction':

"Self-direction is needed from the project group; the dictatorial leadership way doesn't work. I need to guide them in the right direction and trust that they are experts, who know what to do...” (Alex, project manager, Alpha).

According to the project manager (Alex), the development project was planned to include the following broad phases: pre-work (2012), requirements specification (from 2013 forward), and design and implementation (from 2014 forward). These phases were described in the project plan (April 2013). As the project progressed, it became evident that there were different opinions about key technological responsibilities and choices - the IT managers from Alpha and Beta (management group), and the software designers (project group) did not agree on which technology was the right one for the project. In Ben's (IT manager, Beta, management group) opinion, the starting point was that the technical solution for the new system should be 'conservative' - in order to facilitate finding experts in this technology later on. Conversely, Amber, Nathan and Jacob (software designers, Beta, project group), who were considered the technological experts in the project, believed that it made more sense to find several technical options from which the best one could be selected through rigorous testing. More problematically, the managers and software designers both assumed it was their responsibility to find the right technology. As pointed out in Table 1, being part of this project was nonroutine for all members as they served different roles in their home organizations and were recruited into the project on a temporary basis. Thus, uncertainties about responsibilities abounded (cf. Haas, 2006). Furthermore, knowledge sharing between the two groups did not happen. While the software designers (Amber, Nathan and Jacob) were working on finding and testing different technical 
solutions, the IT managers (Ewan and Ben, management group) had given the duty to Alex (project manager) to find a 'conservative' solution for the project. According to Ben, the intent was that they would inform the software designers that this duty was given to Alex, but somehow this did not happen. As a result, the software designers worked on technical issues for several months without comparing their results to those of the IT managers. When it finally transpired that a solution from Omicron (a leading software company) was commissioned by the IT managers, the software designers (Amber and Jacob, Beta) were so insulted that they left the project altogether (September 2013). Amber felt that her knowledge and expertise were not appreciated, while Jacob blamed Ben (IT manager, Beta) for abusing his managerial power. The transition to the design and implementation phase (from 2014 forward) was thus accompanied with changes in the project organization (new personnel in the project group, a new external partner). These changes introduced new uncertainties and placed further demands on knowledge sharing in the project - new members had to be brought up to date with the project and their roles and responsibilities sorted out. While the managers were keen to avoid more conflict, tensions between managers and software developers developed into increasing disagreements between project group members from Alpha and Beta. This conflict can be traced to multiple sources: three major ones being first the uneasiness stemming from the previous joint project, second the unequal distribution of project expenses among the two (Alpha was expected to cover 30\%, Beta 50\%) and finally the perception of Alex (overall project manager) as Alpha's employee who prioritizes Alpha's interests. These created a ripe foundation for power struggles between the two organizations, which in the project group manifested in individuals questioning each other's expertise, blaming others for mistakes, and the like. The conflict even carried over to the external software companies: for example, the software developers of Midén (hired by Alpha in 2015) began questioning the work of Omicron (hired by Beta in 2014), and started re-doing the work the developers of Omicron had done. At the time of writing, we can report that the project is on-going but considerably over budget. The initial estimation was that the project would cost from 4 to 6 million euros, however, it is now estimated that the project may cost as much as 9 million euros. The scheduled delivery date was at the end of 2016, but the current delivery date is estimated to be in early 2018.

We will next consider the role of metaphors and sensemaking in how these events unfolded.

\section{FINDINGS: METAPHORS IN THE PROJECT}

In the following we present our findings through the analysis of prevalent metaphors in different phases of the project. We use the project phases identified by the project manager (Alex) 
(requirements specification, design and implementation) to describe the use of metaphors in sensemaking. We distinguish between metaphors and sensemaking by role: we discuss the differences in the use of metaphors, and the framing of the project by managers and project personnel. We provide further evidentiary support for our arguments in Appendix 3.

\section{REQUIREMENTS SPECIFICATION PHASE (2013)}

In the requirements specification phase of the project, the governing structure of the management, steering and project groups was set up, and the project manager and several key personnel formed the core project team. People were enthusiastic about the possibility of modernizing the system, and this was seen as a new beginning (although recounting of negative experiences in previous projects, and the pre-work phase was also common). The first tensions between the different groups began arising in this phase, when the project personnel were establishing priorities and setting the agenda, often through generative use of metaphorical language (Davison, et al. 2004). In the following, we demonstrate how the different groups used metaphors to make sense of the project, as well as the influence their sensemaking had on the project in this phase.

\section{Employee Sensemaking: 'Breaking the Ice' and Getting Acquainted}

During the setting up of the project, metaphors related to an upcoming journey, as well as everyday life (family and cooking) were common among the project group (see Appendix 3). Given that this was a new project and many project team members did not know each other before, naturally much of the sensemaking was oriented towards 'getting the lay of the land' - learning more about each other, finding ways to work together, negotiating and setting up expectations. For example, Amber (software designer, Beta, project group) noted that a good way of developing the system would be through trial and error, i.e., doing bits and pieces, possibly failing in some cases, backtracking and doing it again until a solution was found. The metaphors of family also came up frequently. The subject matter included issues like marriage, family, home and relationships. Metaphors like 'PROJECT MEMBERS ARE A MARRIED COUPLE' and 'IS PROJECT GOES FROM HONEYMOON TO FIGHT' emerged. Chloe (user rep., Alpha, project group) highlighted how traveling and social events led to project members growing closer together as a family:

"When we go for a drink, we are getting to know each other... [...]; when you travel with others, you get to know each other and we [project members who were traveling together] laughed that we are like married couples... from just a little hint in a conversation we were able to understand each other. And I think that someone from outside would not have understood anything about our discussion...” (Round 1 interview, 2013). 
Traveling together, thus, facilitated early collective sensemaking among the project group. The new project was also described as a "honeymoon" - creating an image of an easy start and a bright future, but also a clear understanding that the honeymoon will not last forever and unexpected challenges are likely to be encountered:

"It will be very interesting if you'll interview us after one year, what I'm going to say then, how well the year went and how these first months of the marriage [laughing] have been so rosy and then after one year we are having a bad fight [laughing]..." (Nicole, user rep., Beta, project group, Round 1 interview, 2013).

About six months later, the first "bad fight" arrived. The project group members were holding crisis meetings, culminating with Amber and Jacob leaving the project. Our second and third round interviews showed a deepening of this trend (particularly a division between the Alpha and Beta organizations) in the project group over 2014 and 2015. While the project team members were expecting possible disagreements from the start, as we demonstrate later, the level of conflict escalated far beyond their expectations. We suggest that it was not only the employees' own sensemaking that influenced future actions in the project - as considered next.

\section{Managerial Sensemaking: Preparing for 'War'?}

Metaphors relating to war, such as 'INFORMATION SYSTEMS PROJECT IS A WAR' have been shown to be common in IS projects (Hirschheim \& Newman, 1991; Kendall \& Kendall, 1993), so we were not surprised to find their presence, particularly given the cross-organizational nature of the project and a history of other challenging development projects involving many of the same people. However, what did surprise us was that in the requirements specification phase (2013), war-related metaphors were used only by people in managerial roles (e.g., Alex, the project manager; multiple IT managers in the management group, see Appendix 3). While the project team members were 'breaking the ice' and talking of honeymoon, the managers were planning for a strategic 'occupation', and based on previous experiences, preparing for 'war'. For example, Ben (IT manager, Beta, management group) described a previous project as:

"A war that wore out both men and women...many come along with a will, and after a while [become] absolutely worn out...". He recollected "a bad fight in one previous project, [where] the legal professionals were marched to the meetings", while he likened the choices of vendors in earlier projects to mines: "in the heat of the moment we chose vendors who used technical solutions they were familiar with and now they are old and the solutions have turned out to be mines..." (Round 1 interview, 2013). 
Given this sensemaking of prior experiences, it is understandable why Ben related the choice of personnel and the sorting out of work responsibilities in the new project to 'occupation' and to 'setting up border fences'. He emphasized particularly the importance of strategic staffing or occupation of the project manager's working group:

"In this occupation, there are some key persons - Isaac (Gamma), Amber and Nathan (from Beta) - with whom we need to support Alex (project manager)" (Ben, manager, Beta, Round 1 interview, 2013).

Alex, the externally hired project manager, described how his own hiring was retold to him in terms of occupying the project with key personnel:

"In preparing how to occupy the project, they could have found a project manager from some user organization or they had to hire the project manager from outside these organizations (like me)..." (Round 1 interview, 2013).

While Alex uses the metaphor of 'occupation', he is very clear that he wants all project team members to feel that they are part of the same unit. As an outsider (not initially part of Alpha, Beta or Gamma), he often felt that the three participating organizations each had their own 'camps' and tried to 'get him on their side', but he also purposefully attempted to avoid that:

"I can clearly see that everyone has their own interest to influence the project manager ...; they [organizations] tried to draw me to their own camps... []. Instead of this I've planned to present the project group as one project organization at the kick-off meeting tomorrow. I have one slide, where are the names of the project members, and what is their home organization. Then I have the second slide, where I have the same names, but there is [project name] after every name. So, it needs to be clear for everyone that although people come from different organizations, we are working for the same project." (Alex, project manager, Round 1 interview, 2013)

Arguably while he uses the metaphors of 'occupation' and 'camps' (likely because other managers do so and it helps him make sense of the situation), his deliberate intention is to guide the project team sensemaking towards unity (not different 'camps').

\section{Diffusion of Managerial Sensemaking: 'War' Spreads Despite Best Intentions}

The managerial engrossment with 'occupation' showed the first inkling of seeping into project team member discussions with an internal crisis meeting held in the summer of 2013: 
"[We had] an internal crisis meeting within the [new] project, [where] they sorted out borderfences, distribution of work and responsibilities..." (Ewan, manager, Alpha, Round 1 interview, 2013).

This crisis meeting discussed, among other things, how Amber (a project group member, Beta) had taken the liberty of having coffee with the project manager (Alex) before the project started. Other members of the project reproached Amber for this, as they thought they should have met the project manager as "one front", and that Amber "exceeded her authority". Making sense of the project as a strategic occupation (in terms of having Alpha, Beta and Gamma's interests represented), thus, first arises among the project personnel during this meeting (through reprimanding people daring to cross the set borders, like Amber did).

Another crisis meeting (within Beta) happened soon after. Here issues around project management were considered and criticized (without the presence of Alex, the project manager). Based on Ben's recommendation, however, this critique of Alex's project management skills was not communicated to him. After this crisis meeting, the software developers of Beta (Amber, Jacob and Nathan) started to voice their dissatisfaction with Alex, who they perceived was doing only what was best for Alpha, blaming him for being “Ewan's vassal, and just bringing Ewan's (manager, Alpha) messages". Despite Alex's best intentions in forming a unified project unit, the notion of Alpha and Beta 'camps' took hold among the software developers of the project team. A few months earlier these same software developers were discussing the project in terms of a journey. A few months after this meeting, the conflict around technological choices between the IT managers (Ewan, Alpha and Ben, Beta) and the software designers from Beta (Amber, Jacob) culminated in both Amber and Jacob leaving the project. Nathan, who had also worked on testing the different possible solutions left later in 2014.

While Amber left the project in 2013, her interview with us from 2014 reveals further evidence of spreading 'war'. It becomes clear that the notion of Alpha and Beta 'camps' increasingly took hold among the software developers based on observing the actions of the managers:

"The management group - it is quite an obscure group, I don't know what kinds of meetings they are having... what Ben (Beta) tells us is totally different from what Alex (project manager, paid by Alpha) says... It happened earlier that Alex explained something to us and I asked about it from Ben, and Ben denied it... so, I don't know who is lying [...] We [technical experts] gave presentations about what we had done, and there was the management group and they were all like, 'Yes', and just asked some minor questions. But then, Ben (Beta) told 
me later what they talked about our presentation and us when we were not in the room any more... Ewan (Alpha) had started to say that 'No, no'.” (Amber, Round 2 interview, 2014)

Of course, the managers in the project did not just use war-related metaphors. Others, related to games, religion, journey, and building were also used in the interviews, but less frequently (see Appendix 3) and they had far less traction in terms of influencing how issues were discussed amongst the managers themselves and at meetings with the project group.

DESIGN AND IMPLEMENTATION PHASE (from 2014 forward)

As already described, the requirements specification phase of the project culminated in serious confrontations and conflicts of power about the choice of appropriate technical solutions. After a short turmoil, things began to stabilize somewhat. In the following we show how this stabilization was based on reflections on the actions taken in the earlier phase. Yet, while the managers adopted new metaphors (moving towards making sense of the project as a collaboration), many of the behaviors from the earlier phase continued unchanged. We provide examples and consider possible reasons for this below.

\section{Managerial Sensemaking: Getting Everyone 'On the Same Page'}

'War' metaphors disappeared from use among the managers during the design and implementation phase (from 2014 onward). Instead, game, journey and nature metaphors became prevalent. Both Ewan and Ben (IT managers at Alpha and Beta, management group) stopped talking about borders and occupation and began using metaphors that were much more related to bringing people together (to the same planet, into the same boat, etc.). For example, Ewan described the conflict with the software developers and the resulting changes in the project group:

"Because the technological choice was very hard, this summer and until even November [2013] we had hard times... because at the same time when we are working, we need to swing our boat and think if we could combine this project with other interest groups... [...]. Some people were not on the same planet in the original team [laughing]. They were clearly people who had different views about how we should do things ... I think after these changes we have got somewhere and the team is much better and workable now...” (Round 2 interview, 2014).

Ewan also reflected on the possibility that the composition and guidance of the project team should have been more carefully considered from the beginning, and the potential shortcomings in his own (and others') leadership in the project:

"Perhaps we could have chosen the first composition of people better or maybe we could have guided the composition better, so that they [project team] would have found a common tune. It 
may be that part of these changes happened because the leadership was not enough, we didn't give enough of a good working model to them..." (Ewan, Round 2 interview, 2014)

Conversely, Ben downplayed the role the management had played in the conflict and dismissed the software developers as petulant children. In the requirements specification phase, Ben was the one emphasizing the importance of 'occupying' the project group with key personnel (Amber, Jacob and Nathan, software developers), holding internal crisis meetings at Beta (criticising the project manager's work, then hiding this discussion), as well as communicating with the software developers behind Ewan and Alex's backs. Now, Ben was talking of the same personnel (particularly Amber and Jacob who left the project) as 'kids whose toys were taken away' and casting suspicion on their motives:

"There was some kind of a sore spot about the fact that Omicron [external] will do the work that [Amber, Jacob and Nathan] have done earlier. They liked the work so much that they were quite sad, and like 'weeping' that they're taking our toy away [laughing] ... [...] they [Amber, Jacob and Nathan] would have liked to use kind of 'sexy' tools and a new and exotic database solution, and yes it might have worked. Anyway, me, Ewan and Sean - we opposed because we want to get a system which still works after 20 years. Those software developers thought that it would have been very nice and motivating to experiment with new tools. But, we IT managers, we were like 'Aha! Are these developers thinking that they can learn those 'sexy' tools and then after that they will apply to another job, where they can get a better salary?' or what was the real motivation [...]" (Round 2 interview, 2014).

Meanwhile, Alex who had been attempting to unify the project team from the start, but had also used the metaphors of 'occupation' and 'camps', continued with the unification aim and also began using different metaphors - talking more about collaboration and 'getting everyone on the same page'. He also reflected on the necessity for better planning on his own part:

"We don't have our own staff in this project, but we have people from three different organizations, and we try to work together. And because all plans are not transparent for one reason or another, the consequence is that planning work is weak at times, because people are not open [...]. It is a real challenge how to get them [different parties involved in the project] to the same place, to the same path, and how to update their view. It's not enough that they will understand where we are, but how we got there..." (Round 2 interview, 2014).

It is interesting to see the stark change in the themes of managerial sensemaking. In the early phase of the project, the management (particularly as represented by Ewan and Ben, IT managers at Alpha and Beta) was preparing for 'war' and strategic 'occupation'. This impacted Alex (project manager), who 
increasingly started seeing and talking about the project work as battles between 'camps'. From there, through internal meetings, this notion of Alpha versus Beta spread to the project team. This culminated in two of the software developers leaving the project. However, in the later phase (from 2014 onwards), both Ewan and Ben made sense of the conflict that transpired (e.g., Amber and Jacob leaving) not in terms 'war' and fighting 'camps', but rather as personnel issues. Both downplayed its impact and were positive that the new team was better and more workable. While Ewan and Alex reflected on the possible shortcomings in their own and others' leadership and planning, Ben dismissed Amber's and Jacob's actions as children being upset over lost 'toys'.

\section{Revised Metaphors; Same Actions: Failure in Managerial Learning}

While the evidence above shows a change in metaphor use and in sensemaking among all the key managers (Alex, Ewan and Ben), the data also suggest that each of the managers made sense of previous events slightly differently. Alex pondered issues of planning and unifying the team; Ewan reflected on leadership; and Ben dismissed the conflict as personnel issues. We have no evidence to suggest that collective sensemaking among the managers took place to discuss the key problems in the project (e.g., the negative feeling of Alpha and Beta 'camps' and how to resolve this). Instead we find that while metaphor use changed among the managers, many of the behaviours continued much as before, promoting further division between Alpha and Beta. For example, in 2014 Omicron is hired as the first external software company to replace Amber and Jacob's expertise. Due to the complex organizational structure of the project (the project did not exist as a separate legal entity until 2016, thus, any contracts had to be signed with either Alpha, Beta or Gamma), the contract Omicron signs is with Beta. While the contract itself can be viewed as a formality, the behaviour by the managers suggests that each of them sees the supplier they have a contract with as the main one. A year after Omicron is hired, Alpha signs an agreement with another software house (Midén). While Ben insists that "the main supplier will be a company called Omicron..." (Round 2 interview, 2014), Alex suggests that the development work is being done according to Midén's consulting report: "Midén created a consulting report, and the experts of the organizations went through it, and they decided that the document is a good starting point. And in fact the development work is based on this document ..." (Round 2 interview, 2014).

By spring 2015 this escalated into an almost comical repetition of the earlier conflict. The software developers of Midén (hired by Alpha) start questioning the work of Omicron (hired by Beta), and even 
start re-doing the work the developers of Omicron had done. Ewan, IT manager of Alpha, poignantly describes the situation as "Groundhog Day"2:

"I've been very frustrated at times... especially when we have had those discussions with different companies. Every new quarter there has been a demand to go through the same issues... when a new company comes, we always need to go through the same arguments and then we will always come to the same conclusions [laughing]... well, it usually takes about two months to go through these discussions... so it's like Groundhog Day [referring to the comedy film] ... that you wake up every morning, in this case once within two months to notice that the situation is still the same..." (Round 3 interview, 2015).

Soon after making this comment Ewan decided to leave the project. To summarize, while the managers were talking of collaboration and 'getting everyone on the same page', they were behaving as if Alpha and Beta were in competition over which organization could hire better software developers and create a better system. Meanwhile, the project team slowly descended into chaos - as described next.

\section{Employee Sensemaking: 'Descending Into Chaos'}

After Amber and Jacob left, the project group, initially quite enthusiastic about working together as a family, were left struggling to pick up the pieces. Amber and Jacob, were among the first project group members to verbalize the war metaphor. However, the notion of Alpha and Beta 'camps' did not disappear with their departure. Many of the original and new members of the project group began increasingly to make sense of the situation as war (see appendix 3). For example, Nicole (user rep., Beta) described:

"We had very bad conflicts in the project group... Alpha people said that Beta people are stupid... Usually when I came to work they [Carol and Chloe from Alpha] started to complain, complain, complain ... at some stage I just blew my top because of their complaining, because it was like a straight attack on our organization... so I needed to say quite straight that shut up, it can't be that you want to dismiss all Beta people, that damn it, you're not going to manage this project alone, we are paying half of this shit... [...] There are situations daily where I need to be quiet and it's better that I don't say what comes to my mind. ... It is not wise to be at every war, sometimes it is better to let some issues go ..." (Round 2 interview, 2014).

\footnotetext{
${ }^{2}$ Groundhog Day is a 1993 American fantasy comedy film. The main character finds himself in a time loop, repeating the same day again and again (Wikipedia).
} 
Chloe (user rep., Alpha) similarly commented on her frustration with the 'camps' or alliances that had formed and were hindering project work. Yet, at the same time, she refers to Alex as our project manager, while referring to Ben as the leader of Beta. The influence of managers and their way of making sense of the situation on the project personnel is also evident here:

"The power play, it's immense, quite unbelievable, and then we have noticed that they [Beta managers who belonged to the management group, e.g., Ben] talk in a different way in the management group than they talk to their subordinates. Our project manager [Alex] had a very hellish position in a phase when there were these problems during last summer and fall [2013], he [Alex] was made a scapegoat for other people's mistakes... Seems like the leaders of Beta talk in a different way to their subordinates than to other people, and have tried to soften this situation to their subordinates." (Chloe, Round 2 interview, 2014).

While the managers could downplay the significance of the conflict in the project trajectory as a whole, the project group did not have the same luxury. They must live with and manage the fall-outs from the conflicts on a daily basis, learning how to pick their battles and deal with the frustrations with the management. There was no mention of traveling together or managing the challenges as a family. The 'camps' were fully formed and influencing the realities of the day-to-day operations. As Wendy (new project group member, Beta, joined in 2014, replacing Nicole) commented:

"It's been sort of a rollercoaster, like, at times it seems good, and like 'Okay, this will be fine', and then the next bomb drops." (Round 3 interview, 2015).

\section{SUMMARY OF KEY FINDINGS}

Our data reveals that while the project members (both managers and employees) used many different kinds of metaphors (see Appendix 3 and Figure 1 below), the war-related metaphors were the most persistent and influential. We can speculate that in the early stage of the project (2013), the war-related metaphors served at least two sensemaking purposes for the management. First, based on prior experiences, the management was preparing for more or less literal 'wars' over the key choices in the development of the new system, but without necessarily wanting to involve their employees in the war. Second, it is also possible that the management was in some ways preparing for post-hoc rationalisations of why certain bad choices were made. This can be seen, for example, in their recollections of well-intended technical choices made in past projects turning out to be mines. Once the war-related metaphors had trickled down to the project group, and distinct 'camps' (particularly between Alpha and Beta) had actually formed, it is possible that the management saw outsourcing the work of Beta's software designers (Amber, Jacob and Nathan) to external companies as a way to ease 
the conflict. However, the problem between 'warring' camps resurfaced between Omicron and Midén. These external software houses were hired by Beta and Alpha, respectively, thus continuing the established way of working with the project organization split into camps along organizational lines, rather than forming a cohesive unit. Interestingly, while the management showed some awareness and frustration in relation to this situation (e.g., Ewan commenting on it as Groundhog Day), there did not seem to be similar awareness with regard to how their own earlier use of metaphors and sensemaking may have played a role in generating the situation in the first place.

We discuss key conclusions that can be drawn from our findings, as well as the theoretical and practical implications next.

\section{DISCUSSION}

The aim of this paper was to explore how cognitive metaphor theory (Lakoff \& Johnson, 1980) can help us understand sensemaking in an IS project. We analyzed a "second system" project (Brooks, 1975), i.e., a system based on experiences with a previous similar system through metaphors that the project members used during the development of a new system. In our case, many of the project members had been involved in previous efforts in the same domain, and it is possible that these prior experiences led to the use of a lot of metaphors of war and travel. It is possible that the long and weary previous projects had prepared the participants for a long and difficult 'battle', which can be seen simultaneously as negative and positive preparation for the future. It is interesting to note that in the very early phases of the project, this preparation for war was reserved to project members in managerial roles only. On the one hand it demonstrates role-situated commitments (Cornelissen, 2012) on the part of the managers, who are making themselves mentally ready for a weary and tough journey and potentially trying to shield project employees from the coming battles and political power plays. On the other hand, it also shows a certain amount of fatalism about the future of the project. While the managers were mentally readying themselves for 'battles', the project employees were bonding as a unit while traveling together, using many metaphors related to everyday life (marriage, etc.) (see Figure 1). As the project progressed, however, the mentality of 'battles between camps' trickled down to the project group, for example through meetings both across and within organizations, and the team became increasingly split into Alpha and Beta camps. 


\begin{tabular}{|c|c|c|c|}
\hline & $\begin{array}{l}\text { Requirements phase (2013) } \\
\text { Data collected: March, April 2013. Major conflict } \\
\text { months: September - November. }\end{array}$ & $\begin{array}{l}\text { Design and Implementation } \\
\text { phase (2014) } \\
\text { Data collected: May, June } 2014 .\end{array}$ & $\begin{array}{l}\text { Design and Implementation phase } \\
\text { (2015): Data collected: May, June, } \\
\text { August } 2015 \text {. }\end{array}$ \\
\hline $\begin{array}{l}\text { M } \\
\text { A } \\
\text { N } \\
\text { A } \\
\text { G } \\
\text { E } \\
\text { R } \\
\text { S }\end{array}$ & $\begin{array}{l}\text { War [See figure 2] } \\
\text { Games and exercising ['big feelings in the game'] } \\
\text { Bible and religion [a technology expert is a theologian] } \\
\text { Nature [ISD creates a world; 'need to act, the world will } \\
\text { not be ready by waiting'; people in different } \\
\text { organizations mold their own clay lump [IS]] } \\
\text { Journey ['keeping the train on the rails'] } \\
\text { Zoo and animal [IS was compared to amoeba, } \\
\text { mammoth; the planning of the project was 'the crossing } \\
\text { of a horse and a camel' [that is neither this or that]] } \\
\text { Building [the building process of the old IS was } \\
\text { compared to the impressive feat of creating 'Saint Isaac's } \\
\text { Cathedral'] } \\
\text { Illness and medication [steering group meetings as the } \\
\text { doctors' clinic; IT was compared to pills ] } \\
\text { Food and clothes [the previous project was compared to } \\
\text { a spaghetti bowl]; } \\
\text { Family [Beta people are 'flirting' with the project } \\
\text { manager] }\end{array}$ & $\begin{array}{l}\text { Games and exercising [a } \\
\text { tournament endurance in project } \\
\text { group] } \\
\text { Bible and Religion [costs of the } \\
\text { project were written down in a pre } \\
\text {-work document, and now this } \\
\text { number has turned into the Holy } \\
\text { Word] } \\
\text { Nature [some people [software } \\
\text { developers] were not on the same } \\
\text { planet in the original team] } \\
\text { Journey [challenge of getting } \\
\text { project members on the same } \\
\text { path]; Zoo and animals [the } \\
\text { project situation resembles the } \\
\text { story about the monkeys, ladders, } \\
\text { and bananas, and how to condition } \\
\text { monkeys [psychological } \\
\text { conditioning]] }\end{array}$ & $\begin{array}{l}\text { Games and exercising [need to act } \\
\text { as a referee; ISD is shadowboxing] } \\
\text { Bible and religion [all project } \\
\text { members do their own version of } \\
\text { Jacob's wrestling [referring to the } \\
\text { Bible's story about Jacob wrestling } \\
\text { with the angel]] } \\
\text { Nature [project manager is a } \\
\text { lightning conductor between project } \\
\text { members] } \\
\text { Journey [there is a need to change } \\
\text { gears in the project; one project } \\
\text { member has not walked enough } \\
\text { miles [referring to life's } \\
\text { experience]] } \\
\text { Toys [project members behave like } \\
\text { they have lost their toys] } \\
\text { Family [there must to be love and } \\
\text { limits in an agile project, it is like } \\
\text { raising children] }\end{array}$ \\
\hline $\begin{array}{l}\mathbf{P} \\
\mathbf{R} \\
\mathbf{O} \\
\mathbf{J} \\
\mathbf{E} \\
\mathbf{C} \\
\mathbf{T}\end{array}$ & $\begin{array}{l}\text { Journey [developing IS is a trial and error, i.e., need to } \\
\text { have a possibility to backtrack if necessary] } \\
\text { Games and exercising ['the organizations have their } \\
\text { own money and resources in the game'; 'arm wrestling } \\
\text { between Alpha and Beta'] } \\
\text { Nature ['going in waves' because of the lack of guidance } \\
\text { and clear roles]; Building [drawings can be ready to the } \\
\text { level of nuts and bolt in a house building, but not in ISD] } \\
\text { Family [project members are like married couples, the } \\
\text { beginning of the project is a honeymoon]; Food and } \\
\text { Clothes [if } 20 \text { people try to cook the soup it is absolutely } \\
\text { not going to work out] }\end{array}$ & $\begin{array}{l}\text { War [See figure 2] } \\
\text { Bible and religion [software } \\
\text { developers are as enthused about } \\
\text { technologies as religious devotees } \\
\text { are about their beliefs] } \\
\text { Toys [Alpha project members are } \\
\text { on the play ground... they just } \\
\text { play with the kids who belong to } \\
\text { the same organization] }\end{array}$ & $\begin{array}{l}\text { War [See figure 2] } \\
\text { Journey [new members feel they } \\
\text { had to jump onto a moving train] } \\
\text { Games and exercising [long IS } \\
\text { project is a marathon; project } \\
\text { members should be one team, } \\
\text { though they do not agree on } \\
\text { everything] }\end{array}$ \\
\hline
\end{tabular}

Figure 1. Overview of different metaphors used by managers and the project group over time

It is interesting to see how the metaphors frame the development of the system across the project phases. Is the new system doomed from the start if the management frames its development as a battle between different camps, or is this just realism that allows the project to proceed despite setbacks? We certainly observed the power of war-related metaphors in framing the development of the project from the outset (see Figure 2). Not surprisingly, we found that the use of metaphors depended on the actor's professional role (Cornelissen, 2012). Project members in managerial roles, whose responsibilities included controlling the project work, made sense of many situations in the early phases of the project (when the responsibilities and rights were being set up) as 'war'. In this phase, occupying the project group with key personnel, setting up border fences and protecting the rights of your own camp were seen as crucial to success by the managers. Conversely, the project group members, whose responsibility it was to carry out the day-to-day tasks, and who had yet to engage fully with the project in these early days, made sense of it as a family relationship, a building and a journey. At this stage, bonding in the project group, while also setting up limits and rules (e.g., expecting "back tracking"), was seen as critical for success by the project personnel. These findings are in line with prior research 
that has shown how sensemakers' use of particular discursive metaphors varies significantly, depending on people's understanding of the issue in question and others' expectations (Cornelissen, 2012).

\begin{tabular}{|c|c|c|c|}
\hline & $\begin{array}{l}\text { Requirements phase (2013) } \\
\text { Data collected: March, April } \\
\text { 2013. Major conflict months: } \\
\text { September - November. }\end{array}$ & $\begin{array}{l}\text { Design and Implementation phase (2014) } \\
\text { Data collected: May, June } 2014 .\end{array}$ & $\begin{array}{l}\text { Design and } \\
\text { Implementation phase } \\
\text { (2015) } \\
\text { Data collected: May, } \\
\text { June, August } 2015 \text {. }\end{array}$ \\
\hline $\begin{array}{l}\text { Mana- } \\
\text { gers }\end{array}$ & $\begin{array}{l}\text { War, fight [previous project] } \\
\text { Mine [choices of vendors in } \\
\text { previous project] } \\
\text { Occupation, Setting up } \\
\text { border fences [choice of } \\
\text { personnel in new project] } \\
\text { Border fences [distribution } \\
\text { of work in new project] } \\
\text { Camps [each organization } \\
\text { had their own 'camp'] }\end{array}$ & No use of 'War' metaphors & $\begin{array}{l}\text { No use of 'War' } \\
\text { metaphors }\end{array}$ \\
\hline $\begin{array}{l}\text { Project } \\
\text { group }\end{array}$ & No use of 'War' metaphors & $\begin{array}{l}\text { Vassal [project members of Beta see project } \\
\text { manager as a vassal of IT manager of Alpha] } \\
\text { Camps ['dichotomy' between Alpha and } \\
\text { Beta] } \\
\text { Attack, victims [project members talk of } \\
\text { 'attacking' each other] } \\
\text { Radical conflicts [project members vs. IT } \\
\text { managers; two project members left the } \\
\text { project] } \\
\text { Wars [project members talk about picking } \\
\text { one's battles carefully] } \\
\text { Politics and power plays [project member of } \\
\text { Alpha wants to warn Alpha people] }\end{array}$ & $\begin{array}{l}\text { Civil war [according to } \\
\text { project member of } \\
\text { Alpha, there was a civil } \\
\text { war in Beta] } \\
\text { A victim of shooting [a } \\
\text { project member of Beta } \\
\text { explains how her } \\
\text { colleague in Beta has } \\
\text { shot her many times] } \\
\text { Bombs [bombs are } \\
\text { falling in Beta } \\
\text { organization] }\end{array}$ \\
\hline
\end{tabular}

Figure 2. Overview of 'War' metaphor use over time

We can draw four key conclusions from our findings. First, our data suggest that most metaphor use in the project was not deliberate or intentional, thus, confirming assertions made by cognitive scientists, who suggest we use metaphors in everyday situations without really noticing them (Chandler, 2002; Lakoff \& Johnson, 1980). Thus, we contend that Ben and Ewan talked of 'occupation' and 'borders' without much thought of the possible consequences, and because these metaphors seemed to fit the situation based on their prior experiences. We have no evidence to suggest the metaphors were selected deliberately and used as part of an intentional strategic sensemaking effort trying to create actual conflicts between Alpha and Beta. Second, our findings indicate that sensemaking in the project overall is best described as "minimal" (Maitlis, 2005) - neither leaders nor stakeholders were trying to actively shape sensemaking; and sensemaking usually happened ad- 
hoc in response to external triggers. Early sensemaking in the project in terms of 'war' was triggered by prior difficult experiences, later sensemaking in terms of 'getting everyone on the same page' was triggerd by conflicts. While Alex displays intention to guide the project team towards unity from the beginning, his efforts seem confounded by his own use of 'occupation' and conflicting 'camp' metaphors. Third, while the metaphor use was not deliberate, and the sensemaking "minimal", both still significantly influenced people's behaviours and actions. Talk of 'war' did not remain talk alone as both managers and employees increasingly behaved accordingly (as if Alpha and Beta formed competing 'camps'). Last but not least, we suggest that this lack of intentionality in metaphor use and "minimal" sensemaking created noticeable difficulties in the project, particularly because of its highly complex and ambiguous, knowledge-intensive nature (cf. Haas, 2006). With high uncertainty, abundance of information on problems and solutions, equivocal relationships between actions and outcomes it is especially critical that teams engage in effective collective sensemaking (identifying key problems, key solutions, deciding what to focus on) (ibid.). Without that the teams are unable to evaluate actions taken, and learn from failed actions. Our findings suggest that "minimal" sensemaking that could easily suffice and be effective in a less complex situation, can in a highly ambiguous situation misdirect team attention away from key problems. In our case, the managers did reflect on the conflicts in the project and adjust their efforts accordingly. However, these adjustments were not coordinated (Ben blamed conflicts on personnel issues, while Ewan and Alex also reflected on planning and management failures), were contradictory (e.g., managers described issues to the management group differently than to their subordinates), and remained superficial (all managers continued to behave in a way that perpetuated different 'camps', for example by partitioning key information sharing to certain organizations or even subgroups). Thus, with the lack of intentionality in metaphor use, those adjustments did not reach the level of actions, hindering learning and, in the long-term, leading to a repetition of the conflicts. One could speculate that this also contributed to the project's delivery being delayed and the budget being exceeded.

We consider the key theoretical implications of our findings next.

\section{PARADOXICAL EFFECTS OF METAPHORS IN SENSEMAKING}

Ricoeur (1977) claims that through metaphors we become aware of our creative capacity for seeing the world from a new perspective. This process, however, is paradoxical: the creative combination of terms in a metaphor produces meaning that has the character of a discovery, yet metaphors are our creations. Through metaphor, we thus create and discover simultaneously. As Kendall and Kendall (1993, p. 2) highlight: "The true effectiveness of metaphors is their almost paradoxical ability to point up dissimilarities and contrasts between two objects while simultaneously demonstrating that there 
are considerable similarities between the objects being compared". In the ISD project we examined, war-related metaphors, for example, suggested to the managers that in the project, like in a war, one should be prepared to confront one's fears, and that people and systems, like soldiers in a war, may become 'injured' or even die. Yet, together with the war metaphors, these same managers used metaphors of children crying over lost toys to make sense of the actual conflict (Figure 1), suggesting that the project, unlike a war, is play acting without "real" consequences. The paradoxical nature of metaphors presents itself also in the seemingly contradictory use of metaphors. In our case this is best implied in the simultaneous appearance of war metaphors in the management and family metaphors in the project group. As Kendall \& Kendall (1993) already suggest, the war metaphor is about chaos and bringing order by directive, while the family metaphor tries to bring order and safety nets into the situation, allowing a certain amount of infighting and internal "family issues" within the project. According to Steen (2008), metaphors may be divertive, informative, persuasive and instructive. Consequently, war-related metaphors can, at the same time, divert attention away from collaboration and unity, but also persuade the project partners that immediate action must be taken to 'win the war'. These actions may then come in the form of trying to reduce conflicts and increase collaboration. To conclude, we contend that in many cases the contradictory effects of metaphors in sensemaking may be associated with whether the choice and use of metaphors is intentional - discussed next.

\section{DIFFERENCE THAT MAKES A DIFFERENCE: INTENTIONALITY OF METAPHOR USE IN SENSEMAKING}

While prior research has indicated the capacity for managers to shape others' interpretations and perceptions strategically through prospective sensemaking (Gioia, et al., 1994), future-oriented sensemaking (Gephart, et al., 2010), and sensegiving (Maitlis and Lawrence, 2007; Vlaar, et al., 2008), and specifically through metaphors (Davison, et al. 2004), our study reveals the non-strategic and unintentional side of this process. Our findings show little evidence of purposeful and strategic shaping of project team members' sensemaking on the part of the management, and rather demonstrate gradual diffusion of managerial interpretations. In short, while we traced the managers as the source of war-related metaphors in this case, it was for them both an intentional creation process (when occupying the project with key personnel) and a serendipitous discovery process (when actual conflicts lead to the 'discovery' that warring camps are not good for the project, and collaboration should be promoted). Our study shows that the managers' non-deliberate, everyday use of metaphors (Lakoff and Johnson, 1980) can diffuse more quickly and broadly and have a more significant influence on employee sensemaking than anticipated. Throughout our study we encountered episodes where it seemed that talk of 'occupation' and 'border fences' was something meant for private conversations within the management group or even between particular managers (e.g., Ewan and 
Ben, IT managers, Alpha and Beta). However, in a cross-organizational project it is clear that the managers do not only communicate with the project group formally as a unified front, but they also communicate informally with the project group members in the same home organization (e.g., Ben from Beta communicates with Amber and Jacob from Beta). As noted by Carol (User rep./product owner, Alpha), these informal communications were often contradictory across the organizations and not in line with what was said officially in meetings. We suggest that making sense of the project as 'war', 'camps' and 'battles' diffused mostly through such informal conversations, the impact of which the managers may be unaware. Since these metaphors were not brought up in official meetings or written in protocols, their spread can be far more insidious than if they were part of the official change strategy. As evident from our data, Alex's formal efforts (captured in his kick-off meeting PowerPoint slides) to promote unity among the project team were far less effective.

In sum, we suggest that whether or not metaphors are used intentionally is an essential part of what makes sensemaking mindful or mindless. Furthermore, we contend this is particularly the case in ambiguous, knowledge-intensive situations, where meanings are multiple, cues are difficult to discern, and actions and outcomes are difficult to link. As cognitive metaphor theory (Lakoff and Johnson, 1980) suggests, individuals are especially likely to rely on metaphors in such situations, because metaphors help them to make abstract and ambiguous things more tangible and understandable. Yet accidental or habitual metaphor use here can also lead project teams into much trouble - much more so than in situations that are clear and not ambiguous. Paradoxically, thus, teams working in complex, ambiguous IS development projects are more likely to use metaphors, however if that use of metaphors is not careful and deliberate, the teams are also more likely to engage in minimal sensemaking (Maitlis, 2005) that is unsuitable for these situations. The result may be failures in learning, unsatisfactory project outcomes, and generally the creation of more chaos, rather than order (cf. Maitlis and Christianson, 2014).

In practice, we argue that deliberate use of metaphors as part of a strategic sensemaking effort can help both leaders and team members guide the project to success.

\section{PRACTICAL IMPLICATIONS: DELIBERATE USE OF METAPHORS IN IS PROJECTS}

Hirschheim and Newman (1991, p. 53) suggest that "in the long term, patterns of 'us vs. them' conflict leads to behaviour, which is difficult to change". As Davison, Boswood and Martinsons (2004) highlight, even the most conventional metaphors may have the highest degree of persuasive power. Considering the rather fatalistic (or realistic) influence of the "war" metaphor, should projects strive to strengthen more positive metaphors in framing the project? Prior research has addressed this question in various ways. 
For example, Kendall and Kendall (1993) recommend that system analysts should aim to understand the metaphors common in users' thinking, but should not limit the number of metaphors, as each metaphor can be useful in highlighting different aspects of the project (cf. Smolander et al., 2008). In our case, we can draw a parallel to managers and project group members. It is especially important for managers (whose role is to guide the project and the team members) to understand different metaphors and use them to highlight different aspects of the project. The family metaphor can highlight that people with different goals can co-exist in a project. This suggests the importance of political negotiations, consensus building and compromise - family members can disagree, but still be supportive of each other. This is quite different from the kinds of elements that the war metaphor highlights - a war has winners and losers, needs a good strategy and a strong leader; war is also oriented towards one centralized goal (Kendall \& Kendall, 1993). Hirschheim and Newman (1991) recommend limiting the use of the common battle or war metaphor. Our findings confirm their insight that making sense of an ISD project as a war may not be the most constructive choice even if it can highlight useful aspects. More importantly, our findings suggest that often the war metaphor may not even be a deliberate choice. This makes understanding its consequences more difficult, yet does not reduce the potential impact of the metaphor on behaviour. Because the war metaphor entails winners and losers, it can lead to threats, coercion and manipulation and is, overall, destructive by nature. It is suggested that reframing it as a constructive conflict may help to transform these issues, so that conflicts are not only expected and enacted, but also resolved through team- and consensus-building and role-playing (Hirschheim and Newman, 1991). However, our research also suggests that care should be taken by managers not to sweep destructive conflicts, such as the one encountered in the studied project, 'under the rug' with the argument that conflicts in big projects are inevitable and 'business as usual'. Managerial sensemaking that moves from strategic 'battles' to 'children missing their toys' is quite disconcerting, and even if not explicitly expressed to the employees, impacts the daily project environment. Even if the managers can keep the broader project goals in mind in a warlike situation, the project employees are likely to focus on their daily tasks, often failing to see the big picture and carrying on their little battles, not realising that these battles will not help the project as a whole to win the war (i.e., succeed).

Evidence and theory suggest that we rely on metaphors and other figures of speech without really noticing them (Lakoff and Johnson, 1980). Thus, any effort of reframing of situations must deal with the complexity of trying to alter the ingrained thought patterns of a great number of different people and is likely to be exceedingly difficult. Our empirical findings demonstrate this difficulty. Accordingly, as a practical contribution, we posit that project leaders should take great care in the choice of the key messages delivered in the constitutive early phases of the project, thereby hopefully 
reducing the necessity of reframing later. For example, instead of "tales from the battlefield" a project would begin by the project members recounting their previous journeys. We believe that this is not coercion or manipulation, but rather an active construction of the narrative about the project. As noted above, the main narratives of the project have a tendency to be very powerful devices of sensemaking that influence the whole project and its outcome. This is perhaps the reason why so many projects are restarted several times (see e.g. Nandhakumar et al. 2005).

\section{CONCLUSION}

This qualitative study analyzed the metaphors used by project members working on a crossorganizational ISD project. The research has its limitations, as always. This study was based on one project in a certain culture and on interviews in a specific language, Finnish. We acknowledge these issues, but we have tried our best to corroborate our findings by relating them to previous research in the field, and we believe that the basic nature of metaphorical thinking in projects, as well as their unanticipated and often insidious influence on sensemaking and actions, can be observed across cultural contexts. The contribution of this paper is threefold: descriptive, theoretical and practical.

First, we describe common metaphors used in an ISD project, providing an overview of the colourful language used to make sense of the different phases of the project. Such an overview gives an idea of the kinds of dominant ways of thinking characteristic to ISD projects. We also demonstrate how managers and project personnel use the metaphors differently to understand the situations in the project and frame the future of the project through them. These links allow us to speculate about the influence of metaphors and sensemaking on the trajectory of the project. Second, we contribute to the theoretical conceptualization of metaphors' role in sensemaking. In extant sensemaking literature, effective sensemaking is generally considered purposeful (or mindful) (Aanestad and Jensen, 2016; Weick \& Sutcliffe, 2006), and metaphors are considered to have an important and fundamental role to play in sensemaking (Davison, et al., 2004; Maitlis and Christianson, 2014). At the same time, cognitive metaphor theory (Lakoff and Johnson, 1980) suggests that metaphor use by individuals is often habitual, unintentional and even mindless. Yet there is very little we know of the interplay between mindless metaphor use and mindful sensemaking. Our study, thus, contributes to the understanding of the role of metaphor in sensemaking by suggesting that in highly ambiguous, knowledge-intensive situations, metaphor use with unclear intentions and purpose will result in these sensemaking devices creating considerable uncertainty instead of order, and rather than facilitating learning, hindering it. Third, as a practical takeaway we claim that it is critically important to set the 
tone of projects in the early phases by providing constructive narratives for the upcoming journey that the team is about to take together.

\section{ACKNOWLEDGEMENTS}

This study was funded by the Academy of Finland (grant number 259454).

\section{References}

Aanestad, M. \& Jensen, T. (2016) Collective Mindfulness in Post-Implementation IS Adaptation Processes. Information \& Organization, 26 (1), 13-27

Brooks, F. (1975) The Mythical Man Month: Essays on Software Engineering. Reading, Mass, USA: Addison-Wesley.

Carlo, J. L., Lyytinen, K. \& Boland Jr, R. J. (2012) Dialectics of Collective Minding: Contradictory Appropriations of Information Technology in a High-Risk Project. MIS Quarterly, 36(4), 10811108 .

Chandler, D. (2002) Semiotics: The Basics. Routlege, New York.

Corley, K.G. \& Gioia, D.A. (2004) Identity ambiguity and change in the wake of a corporate spin-off. Administrative Science Quarterly 49(2), 173-208.

Cornelissen, J.P. (2012) Sensemaking under pressure: The Influence of professional roles and social accountability on the creation of sense, Organization Science, 23, 118-137.

Cornelissen, J. P. \& Clarke, J.S. (2010) Imagining and rationalizing opportunities: Inductive reasoning, and the creation and justification of new ventures. Academy of Management Review, 35, 539-557.

Cornelissen, J. P., Oswick, C., Christensen, L. T. \& Phillips, N. (2008) Metaphor in organizational research: Context, modalities and implications for research - introduction. Organization Studies, $29(1), 7-22$.

Cunliffe, A., \& Coupland, C. (2012) From hero to villain to hero: Making experience sensible through embodied narrative sensemaking. Human Relations, 65(1), 63-88. 
Davison, R.M., Boswood, T.S. \& Martinsons, M.G. (2004) Metaphors to communicate strategic change. $64^{\text {th }}$ Academy of Management Conference, New Orleans, August 6-11

Gephart, R. P., Topal, C. \& Zhang, Z. (2010) Future-oriented sensemaking: Temporalities and institutional legitimation. In T. Hernes \& S. Maitlis (Eds.), Process, sensemaking, and organizing (pp. 275-312). Oxford: Oxford University Press.

Gioia, D. A., Thomas, J. B., Clark, S. M., \& Chittipeddi, K. (1994) Symbolism and strategic change in academia: The dynamics of sensemaking and influence. Organization Science, 5(3), 363-383.

Gioia, D. A. \& Chittipeddi, K. (1991) Sensemaking and sensegiving in strategic change initiation. Strategic Management Journal, 12(6), 433-448.

Grant, D., \& Oswick, C. (1996) Metaphor and organizations. London: Sage Publications.

Heiskanen, A. \& Similä, J. (1992) Gatekeepers in the action structure of software contracting: a case study of the evolution of user-developer relationships. In Proceedings of the 1992 ACM SIGCPR conference on Computer personnel research (Ledered, A.L. Ed.), pp. 11-25, Cincinnati, Ohio, USA.

Haas, M. R. (2006) Knowledge gathering, team capabilities, and project performance in challenging work environments. Management Science, 52(8), 1170-1184.

Hekkala, R., von Hellens, L. \& Newman, M. (2012) Dramaturgical theory as a lens to view project management issues in an IOIS project. In Proceedings of the $20^{\text {th }}$ European Conference on Information Systems (ECIS'12) (Pries-Heje, J., Chiasson, M., Wareham, J., Busquets, X. and Valor, J. Eds), paper 23, Barcelona, Spain.

Hill, R. C., \& Levenhagen, M. (1995) Metaphors and mental models: Sensemaking and sensegiving in innovative and entrepreneurial activities. Journal of Management, 21(6), 1057-1074.

Hirschheim, R. \& Newman, M. (1991) Symbolism and Information Systems Development: Myth, Metaphor and Magic. Information Systems Research, 2(1), 29-62.

Hirschheim R., Klein H. \& Lyytinen K. (1996) Exploring the intellectual structures of information systems development- a social action theoretic analysis. Accounting, Management and Information Technologies, 6(1), 1-64. 
Huber, G. P. \& Daft, R. L. (1987) The information environments of organizations. In F. M. Jablin, L. L. Putnam, K. H. Roberts and L.W. Porter (Eds.), Handbook of organizational communication (pp. 130-164). Newbury Park, CA: Sage Publications.

Ives, B. \& Learmonth, G. (1984) The Information System as a Competitive Weapon. Communication of the ACM, 27(12), 1193-1201.

Kayes, D.C. (2004) The 1996 Mount Everest climbing disaster: The breakdown of learning in teams. Human Relations, 57(10), 1263-1284.

Kendall J.E. \& Kendall, K.E. (1993) Metaphors and Methodologies: Living Beyond the Systems Machine. MIS Quarterly,17(2), 149-171.

Klein, G., Moon, B. \& Hoffman, R. R. (2006) Making sense of sensemaking 1: Alternative perspectives. IEEE Intelligent Systems, 21(4), 70-73.

Lakoff, G. \& M. Johnson (1980) Metaphors We Live By. University of Chicago Press, Chicago.

Maitlis, S. (2005) The social processes of organizational sensemaking. Academy of Management Journal, 48, 21-49.

Maitlis, S. \& Christianson, M. (2014) Sensemaking in Organizations: Taking Stock and Moving Forward, The Academy of Management Annals, 8(1), 57-125.

Maitlis, S. \& Lawrence, T. B. (2007) Triggers and enablers of sensegiving in organizations. Academy of Management Journal, 50(1), 57-84.

Morgan, G. (1986) Images of Organisation. London, Sage Publications.

Nandhakumar, J., Rossi, M. \& Talvinen, J. (2005) The dynamics of contextual forces of ERP implementation. The Journal of Strategic Information Systems 14(2), 221-242.

Nicholson, L. \& Anderson, A.R. (2005) News and Nuances of the Entrepreneurial Myth and Metaphor: Linguistic Games in Entrepreneurial Sense-Making and Sense-Giving. Entrepreneurship Theory and Practice, 29(2), 153-172.

Niergarth, H. (2007) The idiom book: 1010 American English idioms in 101 two-page lessons. Brattleboro, Vt.: Pro Lingua Associates. 
Ricoeur, P. (1977) The Rule of Metaphor: Multi-Disciplinary Studies in the Creation of Meaning in Language, trans. R. Czerny with K. McLaughlin and J. Costello. Toronto: University of Toronto Press.

Robey, D., Wishart, N. A. \& Rodriguez-Diaz, A.G. (1995) Merging the Metaphors for Organizational improvement: Business Process Reengineering as a Component of Organizational Learning. Accounting, Management and Information Technologies, 5(1), 23- 39.

Rouleau, L. (2005) Micro-practices of strategic sensemaking and sensegiving: How middle managers interpret and sell change every day. Journal of Management Studies, 42(7), 1413-1441.

Schultze, U. \& Leidner, D.E. (2002) Studying Knowledge Management in Information Systems Research: Discources and theoretical assumptions. MIS Quarterly, 26(3), 213-242.

Sinclair, J. (1991) Corpus, concordance, collocation. Oxford University Press.

Seiling, J. \& Hinrichs, G. (2005) Mindfulness and constructive accountability as critical elements of effective sensemaking: A new imperative for leaders as sensemanagers. Organization Development Journal, 23(3), 82.

Smith-Doerr, L., Manev, I. M. \& Rizova, P. (2004). The meaning of success: network position and the social construction of project outcomes in an R\&D lab. Journal of Engineering and Technology Management, 21(1), 51-81.

Smolander, K., Rossi, M. \& Purao, S. (2008) Software architectures: Blueprint, Literature, Language or Decision? European Journal of Information Systems, 17, 575-588.

Steen, G. (2008) 'The Paradox of Metaphor: Why We Need a Three-Dimensional Model of Metaphor'. Metaphor and Symbol, 23(4), 213-241.

Vlaar, P. W. L., van Fenema, P. C. \& Tiwari, V. (2008) Cocreating understanding and value in distributed work: How members of onsite and offshore vendor teams give, make, demand, and break sense. MIS Quarterly, 32(2), 227-255.

Walsham, G. (1991) Organizational Metaphors and Information Systems Research. European Journal of information Systems 1(2), 83-94.

Weick, K. E. (1995) Sensemaking in organizations. Thousand Oaks, CA: sage Publications 
Weick, K. E., \& Sutcliffe, K. M. (2003) Hospitals as cultures of entrapment: A re-analysis of the Bristol Royal Infirmary. California Management Review, 45(2), 73-84.

Weick, K. E., \& Sutcliffe, K. M. (2006) Mindfulness and the quality of organizational attention. Organization Science, 17(4), 514-524.

Yu, J., Engleman, R. M. \& Van de Ven, A. H. (2005) The integration journey: An attention-based view of the merger and acquisition integration process. Organization Studies, 26(10), 1501-1528. 
APPENDIX 1: Examples of used metaphors, presented using Lakoff \& Johnson's (1980) notation style

\begin{tabular}{|c|c|c|c|}
\hline $\begin{array}{l}\text { Metaphor } \\
\text { Category }\end{array}$ & $\begin{array}{l}\text { Used } \\
\text { Metaphors }\end{array}$ & $\begin{array}{l}\text { Notation style adapted } \\
\text { from Lakoff \& Johnson } \\
(1980)(' T I M E I S \\
\text { MONEY') }\end{array}$ & Some examples how metaphors were visible in the language of IS project members \\
\hline War/ Battle & $\begin{array}{l}\text { War, March, } \\
\text { Mines, } \\
\text { Minefield, } \\
\text { Occupation, } \\
\text { Battle, Fight }\end{array}$ & $\begin{array}{l}\text { 'INFORMATION SYSTEMS } \\
\text { PROJECT IS A WAR', } \\
\text { 'CHOICE OF VENDORS IS A } \\
\text { MINEFIELD' }\end{array}$ & $\begin{array}{l}\text { "A war that wore out both men and women... many come along with a will, and after a } \\
\text { while [become] absolutely worn out..." } \\
\text { "... had a bad fight in one previous project and the legal professionals were marched to } \\
\text { the meetings" } \\
\text { "In the heat of the moment we chose vendors who used technical solutions they were } \\
\text { familiar with and now they are old and the solutions have turned out to be mines..." }\end{array}$ \\
\hline $\begin{array}{l}\text { Games / } \\
\text { Exercising }\end{array}$ & $\begin{array}{l}\text { Games, } \\
\text { Team, } \\
\text { Exercising, } \\
\text { Competitor }\end{array}$ & $\begin{array}{l}\text { 'IS DEVELOPMENT IS A } \\
\text { GAME / EXERCISING' }\end{array}$ & $\begin{array}{l}\text { "We are a little bit novice in these issues, so we were not able to think about it in terms of } \\
\text { how to play the game..."; "If there is only one person who has an important role and is } \\
\text { reluctant to play with others, there is a very big risk that the job will not go well..." }\end{array}$ \\
\hline Nature & $\begin{array}{l}\text { Lightning } \\
\text { conductor, } \\
\text { Drift, Clay } \\
\text { lump, World }\end{array}$ & $\begin{array}{l}\text { 'ISD CREATES A WORLD', } \\
\text { 'ISD WORK } \\
\text { ENVIRONMENT IS } \\
\text { NATURE', 'INFORMATION } \\
\text { SYSTEM IS A LUMP OF } \\
\text { CLAY' }\end{array}$ & $\begin{array}{l}\text { "I wish that there would be a possibility to do a project, so that the things would be done } \\
\text { correctly right from the beginning.... we should not just define something on paper for } \\
\text { one year, because the world does not work that way ..."; "people in different } \\
\text { organizations will continue to mold their own clay lump..." }\end{array}$ \\
\hline $\begin{array}{l}\text { Family / } \\
\text { Couple }\end{array}$ & $\begin{array}{l}\text { A married } \\
\text { couple, } \\
\text { Honeymoon, } \\
\text { Man, Child }\end{array}$ & $\begin{array}{l}\text { 'PROJECT MEMBERS ARE } \\
\text { A MARRIED COUPLE', 'IS } \\
\text { PROJECT GOES FROM } \\
\text { HONEYMOON TO FIGHT' }\end{array}$ & $\begin{array}{l}\text { "When we go for a drink, we are getting to know each other... [...]; when you travel with } \\
\text { others, we get to know each other and we laughed that we are like married couples...". } \\
\text { "everything seems so rosy, but we should have clear terms of agreement (about what to } \\
\text { do when the 'honeymoon' is over)" }\end{array}$ \\
\hline Journey & Baggage, & 'INFORMATION SYSTEM IS & "We improved, improved and improved... all interface work had to be done quickly and it \\
\hline
\end{tabular}




\begin{tabular}{|c|c|c|c|}
\hline & $\begin{array}{l}\text { Path, Way, } \\
\text { Train, Back } \\
\text { tracking, } \\
\text { Green lights }\end{array}$ & $\begin{array}{l}\text { BAGGAGE', 'ISD WORK IS } \\
\text { A PATH', 'ISD WORK IS A } \\
\text { MOVING TRAIN', 'ISD } \\
\text { WORK IS BACK } \\
\text { TRACKING' }\end{array}$ & $\begin{array}{l}\text { became such a baggage..."; "I hope that everyone would have an open mind and they } \\
\text { would not get bored of negotiating and will not leave to go down their own paths..." }\end{array}$ \\
\hline Building & $\begin{array}{l}\text { Saint Isaac's } \\
\text { Cathedral, } \\
\text { Nuts and } \\
\text { bolts, House } \\
\text { building }\end{array}$ & $\begin{array}{l}\text { 'ISD IS AN ETERNAL } \\
\text { PROJECT', 'ISD WORK IS } \\
\text { DIFFERENT THAN HOUSE } \\
\text { BUILDING', 'ISD WORK IS } \\
\text { HOUSE BUILDING' }\end{array}$ & $\begin{array}{l}\text { "Drawings can be ready to the level of nuts and bolts in a house building project, but } \\
\text { software issues are different; it is not possible to know everything in the beginning ..."; } \\
\text { "instead of wires bolted to a wall, there are plugs, and depending on the situation it is } \\
\text { possible to change what we use. The situation is the same here; we need the same kind of } \\
\text { planning paradigm ..." }\end{array}$ \\
\hline $\begin{array}{l}\text { Illness and } \\
\text { Medication }\end{array}$ & $\begin{array}{l}\text { Pain, } \\
\text { Balance of } \\
\text { horror, } \\
\text { Medicine } \\
\text { (pills) }\end{array}$ & $\begin{array}{l}\text { 'STEERING GROUP } \\
\text { MEETING IS A DOCTOR'S } \\
\text { CLINIC' }\end{array}$ & $\begin{array}{l}\text { "I've had a feeling in some steering group meetings like I'm at a doctor's clinic, and } \\
\text { there are two doctors and I'm having a serious illness. And one doctor says that you need } \\
\text { to take these green pills and another doctor says that you need to take the red pills...I } \\
\text { don't have the competence to evaluate which one of these doctors is right...it causes huge } \\
\text { insecurity... And the truth is that nobody can know because the development of } \\
\text { technologies is so fast. The decision about which pills I should have taken can only be } \\
\text { evaluated afterwards... and I think that it's very important that [...] we will keep to the } \\
\text { focus and do the best solutions... and then we need to be brave enough to say that let's } \\
\text { take these red pills now and lets see where it goes...". }\end{array}$ \\
\hline $\begin{array}{l}\text { Bible and } \\
\text { Religion }\end{array}$ & $\begin{array}{l}\text { Jesus, } \\
\text { Theologists, } \\
\text { Religions }\end{array}$ & $\begin{array}{l}\text { 'INFORMATION SYSTEM IS } \\
\text { JESUS' and } \\
\text { 'A TECHNOLOGY EXPERT } \\
\text { IS A THEOLOGIST' }\end{array}$ & $\begin{array}{l}\text { 'The system is coming soon, are you ready' (Erin, User, Alpha). In some countries many } \\
\text { people have probably seen labels in public places, which this joke is based on: 'Jesus is } \\
\text { coming soon, are you ready'. } \\
\text { "I've noticed that in this profession they have very strong opinions like theologists have } \\
\text { or could I say that religions have; like we are Buddhists and this is the truth and other } \\
\text { religions have another truth... there are a lot of people working in this profession } \\
\text { [technology experts] who are very passionate and who have very strong opinions..." }\end{array}$ \\
\hline $\begin{array}{l}\text { Zoo / } \\
\text { Animals }\end{array}$ & $\begin{array}{l}\text { Amoeba, } \\
\text { Mammoth, } \\
\text { Fly }\end{array}$ & $\begin{array}{l}\text { 'INFORMATION SYSTEM IS } \\
\text { AMOEBA', 'INFORMATION } \\
\text { SYSTEM IS MAMMOTH', } \\
\text { 'IS PROJECT IS }\end{array}$ & $\begin{array}{l}\text { "She (Debra) told me that this is a small project but in the next meeting she told that this } \\
\text { project is so big, this is a project that will cost millions..., so in a few days the project } \\
\text { changed into a mammoth from her point of view...". }\end{array}$ \\
\hline
\end{tabular}




\begin{tabular}{|c|c|c|c|}
\hline & & MAMMOTH' & "the system is a huge amoeba" \\
\hline $\begin{array}{l}\text { Food / } \\
\text { Clothes }\end{array}$ & $\begin{array}{l}\text { Evening } \\
\text { dress, } \\
\text { Making } \\
\text { soup, } \\
\text { Spaghetti }\end{array}$ & $\begin{array}{l}\text { 'INFORMATION SYSTEM IS } \\
\text { AN EVENING DRESS'; 'ISD } \\
\text { PROJECT IS SPAGHETTI } \\
\text { BOWL OR MAKING SOUP' }\end{array}$ & $\begin{array}{l}\text { "I assume that the system is a new one. It is like the situation of waiting to get a new } \\
\text { evening dress, but instead of it you'll get an old one with just some new decorations but } \\
\text { you can see an old coffee stain still in it..."; "if } 20 \text { people try to cook the soup it is } \\
\text { absolutely not going to work out..." }\end{array}$ \\
\hline
\end{tabular}


APPENDIX 2: On Finnish language and culture

There are a little over five million native Finnish speakers in the world. In our study, most participants were at least bi-lingual (speaking both Finnish and English), however, many Finns also speak fluent Swedish. Regardless, all interviews were conducted in the respodnents' native language Finnish.

The Finnish culture is young and urbanization is very recent, the major wave of moving from villages to cities took place in the 1960s and 1970s. Finland was also a very poor country until the 1930s. This, together with two wars with the Soviet Union and a life of balancing between the East and West, has kept self-reliance and survival instincts strong in the minds of Finns. Still, after 70 years of peace, the Finnish identity builds strongly on wartime experiences and surviving between the superpowers of the Second World War.

According to Olli Alho, Finns put great emphasis on words, which means that small talk is to be avoided and it is better to be silent than to talk without something to say (http://finland.fi/lifesociety/a-guide-to-finnish-customs-and-manners/). Promises and handshakes are taken by their face value, and Finns have huge problems for example with interpreting an invitation to visit someone's home some time, as in Finland this would mean that it would be actually arranged in not too distant future. A handshake is still seen as an affirmation of a contract arrangement.

There is a state church in Finland, the Evangelical-Lutheran Church, to which about $75 \%$ of the citizens belong. The country is fairly secular, but Lutheran work ethos can be easily identified in the work culture. Furthermore, Finns are punctual to the degree that they tend to inform others by messages when they are 3-5 minutes late. Due to the long and dark winter and short summer with long days, Finns observe carefully the passing of seasons, and one can speculate that even the time of the year affects the use of metaphors. 
APPENDIX 3: Individual usage of metaphors over time and the frequency numbers for different metaphors.

\section{PROJECT GROUP:}

\begin{tabular}{|c|c|c|c|}
\hline \multirow{2}{*}{$\begin{array}{l}\text { Alex (Project manager, Alpha) } \\
\text { (In project group, but in a } \\
\text { managerial role) }\end{array}$} & 2013 & 2014 & 2015 \\
\hline & $\begin{array}{l}\text { War and battle (4) } \\
\text { Games and exercising (1) } \\
\text { Family / Couple (1) } \\
\text { Zoo and animals (1) }\end{array}$ & $\begin{array}{l}\text { Game and exercising (1) } \\
\text { Journey (1) } \\
\text { Bible and religion (1) } \\
\text { Zoo and animals (2) }\end{array}$ & $\begin{array}{l}\text { Bible (1) } \\
\text { Journey (1) } \\
\text { Games and exercising (1) } \\
\text { Nature (1) } \\
\text { Toys (1) }\end{array}$ \\
\hline \multirow{2}{*}{$\begin{array}{l}\text { Amber (Software designer, Beta, } \\
\text { project group) }\end{array}$} & 2013 & 2014 & 2015 \\
\hline & $\begin{array}{l}\text { Nature (1); } \\
\text { Journey (1) } \\
\text { Building (1) }\end{array}$ & $\begin{array}{l}\text { War (2) } \\
\text { Had left the project when the second } \\
\text { round interview was done }\end{array}$ & No interview. \\
\hline \multirow{2}{*}{$\begin{array}{l}\text { Nicole (User rep./ product owner, } \\
\text { Beta) }\end{array}$} & 2013 & 2014 & 2015 \\
\hline & $\begin{array}{l}\text { Games and exercising (1) } \\
\text { Nature (1) } \\
\text { Family / Couple (1) } \\
\text { Building (1) }\end{array}$ & $\begin{array}{l}\text { Food, clothes, 'toys' (1) } \\
\text { War (1) }\end{array}$ & $\begin{array}{l}\text { On maternity leave. Wendy is } \\
\text { substituting for her. }\end{array}$ \\
\hline \multirow{2}{*}{$\begin{array}{l}\text { Wendy (User rep./product owner, } \\
\text { Beta) }\end{array}$} & 2013 & 2014 & 2015 \\
\hline & Not part of the project yet. & Started in the project in 2014. & War (5) \\
\hline
\end{tabular}




\begin{tabular}{|l|l|l|l|}
\hline $\begin{array}{l}\text { Carol (User rep./product owner, } \\
\text { Alpha) }\end{array}$ & $\mathbf{2 0 1 3}$ & $\mathbf{2 0 1 4}$ & $\mathbf{2 0 1 5}$ \\
\cline { 2 - 4 } & No metaphors. & $\begin{array}{l}\text { War and battle (2) } \\
\text { Bible and religion (1) }\end{array}$ & No metaphors. \\
\hline $\begin{array}{l}\text { Chloe (User rep./product owner, } \\
\text { Alpha) }\end{array}$ & $\mathbf{2 0 1 3}$ & $\mathbf{2 0 1 4}$ & $\mathbf{2 0 1 5}$ \\
\cline { 2 - 4 } & $\begin{array}{l}\text { Games and exercising (1) } \\
\text { Family / Couple (1) } \\
\text { Food and clothes (1) }\end{array}$ & No metaphors. & $\begin{array}{l}\text { Journey (1) } \\
\text { War (2) }\end{array}$ \\
\hline Jacob (Software designer, Beta) & $\mathbf{2 0 1 3}$ & $\mathbf{2 0 1 4}$ & $\mathbf{2 0 1 5}$ \\
\cline { 2 - 4 } & No metaphors. & $\begin{array}{l}\text { No interview. Not part of the project } \\
\text { anymore (left the project in Sept. 2013 }\end{array}$ & No interview. \\
\hline $\begin{array}{l}\text { Nathan (Product owner, Beta, project } \\
\text { group) }\end{array}$ & $\mathbf{2 0 1 3}$ & $\mathbf{2 0 1 4}$ & $\mathbf{2 0 1 5}$ \\
\cline { 2 - 4 } & No metaphors. & Left the project in 2014. No interview. & No interview. \\
\hline $\begin{array}{l}\text { Isaac (IS manager, Gamma, project } \\
+ \text { steering group) }\end{array}$ & $\mathbf{2 0 1 3}$ & $\mathbf{2 0 1 4}$ & $\mathbf{2 0 1 5}$ \\
\cline { 2 - 4 } & Games and exercising (1) & No interview. & $\begin{array}{l}\text { War (2) } \\
\text { Games and exercising (1) }\end{array}$ \\
\hline
\end{tabular}

\section{MANAGEMENT GROUP:}

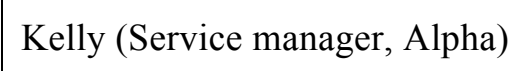

\begin{tabular}{|l|}
2013 \\
\hline Nature (1)
\end{tabular}

2014

2015

No interview. Left the project in June No interview. 2013 (retired). 


\begin{tabular}{|c|c|c|c|}
\hline & $\begin{array}{l}\text { Family / Couple (1) } \\
\text { Journey (1) } \\
\text { Building (1) } \\
\text { Zoo and animals (1) }\end{array}$ & & \\
\hline \multirow[t]{2}{*}{ Leslie (Service manager, Alpha) } & 2013 & 2014 & 2015 \\
\hline & $\begin{array}{l}\text { No interview. Started in June } \\
\text { 2013. Worked in parallel } \\
\text { with Kelly, and substituted } \\
\text { Kelly. }\end{array}$ & $\begin{array}{l}\text { No metaphors. } \\
\text { Left the project and Alpha } \\
\text { organization in 2014. Erin (from the } \\
\text { steering group) replaced her. }\end{array}$ & No interview. \\
\hline \multirow[t]{2}{*}{ Ewan (IT manager, Alpha) } & 2013 & 2014 & 2015 \\
\hline & $\begin{array}{l}\text { War and battle (3) } \\
\text { Journey (1) } \\
\text { Building (2) }\end{array}$ & $\begin{array}{l}\text { Nature (1) } \\
\text { Journey (1) }\end{array}$ & No metaphors. \\
\hline \multirow[t]{2}{*}{ Ben (IT manager, Beta) } & 2014 & 2014 & 2015 \\
\hline & $\begin{array}{l}\text { War and battle (5) } \\
\text { Nature (1) } \\
\text { Journey (1) } \\
\text { Zoo and animals (1) }\end{array}$ & $\begin{array}{l}\text { Journey (1) } \\
\text { Zoo and animals (1) } \\
\text { Food, clothes, toys (1) }\end{array}$ & No metaphors. \\
\hline \multirow[t]{2}{*}{ Sean (IT manager, Gamma) } & 2013 & 2014 & 2015 \\
\hline & No metaphors. & Left the project. (Retired) & $\begin{array}{l}\text { No interview. Not part of the } \\
\text { project anymore. }\end{array}$ \\
\hline Leon (Service manager, Gamma) & 2013 & 2014 & 2015 \\
\hline
\end{tabular}




\begin{tabular}{|l|l|l|l|}
\hline & $\begin{array}{l}\text { Games and exercising (1) } \\
\text { Journey (1) }\end{array}$ & No metaphors. & No metaphors. \\
\hline \multirow{2}{*}{ Lily (Project leader, Beta) } & $\mathbf{2 0 1 3}$ & $\mathbf{2 0 1 4}$ & $\mathbf{2 0 1 5}$ \\
\cline { 2 - 4 } & $\begin{array}{l}\text { Illness and medication (1) } \\
\text { Bible and religion (1) } \\
\text { Food and clothes (1) }\end{array}$ & No metaphors. & Games and exercising (1) \\
\hline
\end{tabular}

